\title{
Observations of aerosol optical properties at a coastal site in Hong Kong, South China
}

\author{
Jiaping Wang ${ }^{1,2,3,4}$, Aki Virkkula ${ }^{1,2,3,5,6}$, Yuan Gao ${ }^{4,7}$, Shuncheng Lee ${ }^{4}$, Yicheng Shen ${ }^{1,2,3}$, Xuguang Chi ${ }^{1,2,3}$, \\ Wei Nie ${ }^{1,2,3}$, Qiang Liu ${ }^{1,2,3}$, Zheng $\mathrm{Xu}^{1,2,3}$, Xin Huang ${ }^{1,2,3}$, Tao Wang ${ }^{4}$, Long Cui ${ }^{4}$, and Aijun Ding ${ }^{1,2,3}$ \\ ${ }^{1}$ Joint International Research Laboratory of Atmospheric and Earth System Sciences, Nanjing, China \\ ${ }^{2}$ Institute for Climate and Global Change Research \& School of Atmospheric Sciences, Nanjing University, \\ Nanjing, 210023, China \\ ${ }^{3}$ Collaborative Innovation Center of Climate Change, Jiangsu Province, China \\ ${ }^{4}$ Department of Civil and Environmental Engineering, The Hong Kong Polytechnic University, Hung Hom, \\ Kowloon, Hong Kong SAR, China \\ ${ }^{5}$ Finnish Meteorological Institute, Helsinki, Finland \\ ${ }^{6}$ Department of Physics, University of Helsinki, Helsinki, Finland \\ ${ }^{7}$ Department of Civil Engineering, the Chu Hai College of Higher Education, Castle Peak Bay, Hong Kong SAR, China
}

Correspondence to: Jiaping Wang (jiaping16@126.com) and Shuncheng Lee (shun-cheng.lee@polyu.edu.hk)

Received: 18 September 2016 - Discussion started: 18 October 2016

Revised: 22 January 2017 - Accepted: 23 January 2017 - Published: 22 February 2017

\begin{abstract}
Temporal variations in aerosol optical properties were investigated at a coastal station in Hong Kong based on the field observation from February 2012 to February 2015. At $550 \mathrm{~nm}$, the average light-scattering $\left(151 \pm 100 \mathrm{Mm}^{-1}\right)$ and absorption coefficients $\left(8.3 \pm 6.1 \mathrm{Mm}^{-1}\right)$ were lower than most of other rural sites in eastern China, while the single-scattering albedo $(\mathrm{SSA}=0.93 \pm 0.05)$ was relatively higher compared with other rural sites in the Pearl River Delta (PRD) region. Correlation analysis confirmed that the darkest aerosols were smaller in particle size and showed strong scattering wavelength dependencies, indicating possible sources from fresh emissions close to the measurement site. Particles with $D_{\mathrm{p}}$ of $200-800 \mathrm{~nm}$ were less in number, yet contributed the most to the light-scattering coefficients among submicron particles. In summer, both $\triangle \mathrm{BC} / \triangle \mathrm{CO}$ and $\mathrm{SO}_{2} / \mathrm{BC}$ peaked, indicating the impact of nearby combustion sources on this site. Multi-year backward Lagrangian particle dispersion modeling (LPDM) and potential source contribution (PSC) analysis revealed that these particles were mainly from the air masses that moved southward over Shenzhen and urban Hong Kong and the polluted marine air containing ship exhausts. These fresh emission sources led to low SSA during summer months. For winter and autumn months, contrarily, $\Delta \mathrm{BC} / \Delta \mathrm{CO}$ and $\mathrm{SO}_{2} / \mathrm{BC}$ were rela-
\end{abstract}

tively low, showing that the site was more under influence of well-mixed air masses from long-range transport including from South China, East China coastal regions, and aged aerosol transported over the Pacific Ocean and Taiwan, causing stronger abilities of light extinction and larger variability of aerosol optical properties. Our results showed that ship emissions in the vicinity of Hong Kong could have visible impact on the light-scattering and absorption abilities as well as SSA at Hok Tsui.

\section{Introduction}

Atmospheric aerosol strongly affects the earth's radiative balance by scattering and absorbing incoming solar radiation, which, however, is still a large source of uncertainties in global climate forcing assessment (Stocker et al., 2013). The aerosol optical properties are responsible for the direct aerosol radiative forcing, depending on aerosol chemical composition and microphysical properties. Relative to another major component of radiative forcing, greenhouse gases, the shorter atmospheric lifetime of aerosols leads to more localized effects and regional differences in aerosol optical properties. Due to the spatial and temporal differences 
of aerosol optical properties caused by the complex distribution of tropospheric aerosols, field monitoring of aerosol optical properties in different regions around the world is critical for exploring the variations in aerosol radiative forcing. Among the major aerosol radiative forcing drivers, mineral dust, sulfate, nitrate, and organic carbon generally have negative radiative forcing. Contrarily, absorbing aerosols, like black carbon (BC), can strongly absorb visible light, enhancing the warming effect of the atmosphere (Jacobson, 2001; Babu and Moorthy, 2001; Ding et al., 2016).

Light absorption and scattering of different kinds of aerosols have distinct wavelength dependencies that are approximately proportional to $\lambda^{-\mathrm{AAE}}$ or $\lambda^{-\mathrm{SAE}}$, respectively, where $\lambda$ is the wavelength and AAE and SAE are the Ångström exponents of absorption and scattering, respectively. Hence, the wavelength dependency of aerosol light scattering and absorption has been recognized as an efficient index to distinguish aerosol types (e.g., Russell et al., 2010; Moosmüller and Chakrabarty, 2011; Devi et al., 2016). For instance, BC can strongly absorb light at all visible wavelengths, while other light-absorbing aerosols (some organic aerosol, soil, and dust) absorb more blue light than red light (Moosmüller et al., 2011; Bond et al., 2013; Ding et al., 2016). Therefore, the absorption Ångström exponent (AAE) is often related to the dominant absorbing aerosol type for a mixture of aerosols (Cazorla et al., 2013). The AAE in externally mixed $\mathrm{BC}$-dominated regions has been reported to be around 1 (Hegg et al., 2002; Bond and Bergstrom, 2006; Bond et al., 2013), while it is greater than 1 for some organic aerosol from biomass smoke and mineral dust due to their diverse light absorbing abilities at different wavelength ranges (Kirchstetter et al., 2004; Russell et al., 2010; Valenzuela et al., 2015; Devi et al., 2016). Moreover, studies have shown that $\mathrm{AAE}$ of $\mathrm{BC}$ has a large variability, depending on the size of $\mathrm{BC}$ cores and coating thickness (e.g., Lack and Cappa, 2010). For non-coated BC with small diameters (e.g., $10 \mathrm{~nm}$ ), AAE is close to 1, but large BC cores can have AA E less than 1 (e.g., Gyawali et al., 2009; Lack and Cappa, 2010). For coated BC particles, laboratory measurements of Schnaiter et al. (2005) reported that thickly coated BC by $\alpha$-pinene plus ozone SOA could decrease the AAE of up to 0.8 . Coating of $\mathrm{BC}$ by purely scattering material may also result in AAE up to about 1.8 (Gyawali et al., 2009; Lack and Cappa, 2010). The scattering Ångström exponent (SAE) is often regarded as a qualitative indicator of the dominating particle size, that is, large values ( $\mathrm{SAE}>2$ ) indicate a large contribution of small particles and small values $(\mathrm{SAE}<1)$ a large contribution of large particles. For instance, Delene and Ogren (2002) reported that the influence of large sea-salt particles led to lower SAE. However, this interpretation is not quite unambiguous, as was shown, for example, by Schuster et al. (2006) and Virkkula et al. (2011). The SSA is the ratio of scattering to extinction coefficient, i.e., the sum of scattering and absorption coefficients. It equals 1 for purely scattering aerosol and is clearly lower, approximately 0.3 , for pure
BC particles (e.g., Schnaiter et al., 2003; Mikhailov et al., 2006). SSA varies significantly for smoke of different origin and age and correlates with the presence of $\mathrm{BC}$ in the combustion products (e.g., Dubovik et al., 2002).

There are several ways to assess the sources of aerosols, for instance by comparing observed particle concentrations with other tracers. $\mathrm{CO}$ is a by-product of the incomplete oxidation. Due to its long lifetime (about 1-2 months) in the troposphere, $\mathrm{CO}$ can act as a tracer of anthropogenic emissions (Jennings et al., 1996). A strong positive correlation between $\mathrm{BC}$ and $\mathrm{CO}$ has been found in previous studies concerning source identifications (Pan et al., 2011; Jennings et al., 1996). The BC / CO ratio is considered a good indicator to determine $\mathrm{BC}$ emission and to recognize source characteristics. Also, the emission ratio of $\mathrm{BC}$ and $\mathrm{CO}$ varies significantly from different sources, making it an effective index for validating emission inventories (Girach et al., 2014). The $\mathrm{SO}_{2} / \mathrm{BC}$ ratio can be also used for assessing the sources since both $\mathrm{BC}$ and $\mathrm{SO}_{2}$ are emitted in fossil fuel combustion (Bond et al., 2013).

The Pearl River Delta (PRD) region in southern China has undergone fast industrialization with increasing emissions of particulate and gaseous pollutants (Wang et al., 2003). In particular, the growing crisis of high particulate matter (PM) levels in the Pearl River Delta (PRD) region is of great concern due to its adverse effects on regional and continental atmospheric environment (Wang et al., 2009; Ding et al., 2013; Lam et al., 2005; Liu and Chan, 2002; Verma et al., 2010). Hong Kong is a typical coastal city in the PRD region. Under the influence of the East Asian monsoon, this region is controlled by the southerly winds bringing marine inflow from the South China Sea in summer, while in winter it is downwind from the North China Plains and East China and is dominated by the continental outflow (Ding et al., 2013; Lam et al., 2001; Zhou et al., 2013). Thus, it is an ideal place for exploring the characteristics of optical properties for continental and marine aerosols.

There have been studies concerning aerosol optical properties and light-absorbing aerosols in the PRD region. Man and Shih (2001) did field observations of light-scattering and absorption coefficients from September 1997 to April 1999 in Hong Kong. Cheng et al. (2006a) investigated the seasonal variation patterns of $\mathrm{BC}$ concentrations in Hong Kong as well as the potential sources of BC by continuous measurement from June 2004 to May 2005, using a model AE-42 Aethalometer (Magee Scientific Inc., Berkeley, CA). Cheng et al. (2008) presented the 1-month record of aerosol optical measurements with related chemical apportionment at Xinken in the PRD region and reported a relatively low SSA at this polluted rural site. Mixing states of light-absorbing aerosols were also investigated using optical closure experiments during the campaign (Cheng et al., 2006b; Tan et al., 2016). However, long-term observations of several key aerosol optical properties (including wavelength dependencies of light scattering and absorption SSA), and studies on 
the relationships between optical properties and particle size as well as their quantitative linkage to multi-scale transport) have been limited in Hong Kong over the past decade.

In this study, we aim at demonstrating the temporal variations of aerosol optical properties at a coastal station in Hong Kong and investigating the relationships between aerosol optical properties and size distributions based on field observations. Source analyses are conducted by comparing observed $\mathrm{BC}-\mathrm{CO}$ ratios as well as the $\mathrm{SO}_{2}-\mathrm{BC}$ ratios. Transport pattern and origins of aerosols were quantitatively studied based on Lagrangian particle dispersion modeling (LPDM). Characteristics of local aerosol optical properties dominated by different aerosol source regions were also compared and illustrated.

\section{Methodology}

\subsection{Sampling site}

The Hok Tsui (HT) monitoring station is situated on the southeast tip of Hong Kong Island facing the South China Sea $\left(22.22^{\circ} \mathrm{N}, 114.25^{\circ} \mathrm{E} 60 \mathrm{~m}\right.$ above sea level) with an almost vertical drop to the sea. This station has a view of the sea for over $180^{\circ}$ from the northeast to the southwest and is $20 \mathrm{~km}$ away from the urban area of Hong Kong on the northwest. Owing to the characteristics of the location mentioned above, it is an ideal background monitoring site for identifying both the long-range transport of polluted continental/marine air mass caused by anthropogenic emissions and relatively clean marine air mass in different seasons. For more details about the HT site, please refer to Wang et al. (2009) and papers cited therein.

\subsection{Absorption measurement}

Light-absorption measurement was conducted using a model AE-31 Aethalometer (Magee Scientific Company, Berkeley, California, USA) from 1 February 2012 to 30 September 2013 and 1 March 2014 to 28 February 2015. Sample air was obtained through a stainless steel inlet with a $\mathrm{PM}_{2.5}$ cut-off, protected with a rain cap. Prior to entering the instrument, sample air was heated to ensure a moderate relative humidity. The sample inlet was approximately $1.5 \mathrm{~m}$ above the roof of the measurement station building, which was about $4 \mathrm{~m}$ above the ground. The sample flow provided by the internal pump was set to $4.0 \mathrm{~L} \mathrm{~min}^{-1}$. The AE-31 Aethalometer performs continuous measurements of BC concentrations at seven wavelengths $(370,470,520,590$, 660,880 and $950 \mathrm{~nm}$ ) with a time resolution of $5 \mathrm{~min}$. In this work, without specific notes, $\mathrm{BC}$ concentrations refer to the aethalometer data measured at $\lambda=880 \mathrm{~nm}$. Sample flow on the Aethalometer display was checked once a week to ensure the flow was within $0.2 \mathrm{~L} \mathrm{~min}^{-1}$ of previous week and flow calibration was conducted once a month using an independent flowmeter. The inlet cyclone was cleaned every month.
In order to correct the systematic errors of filter-based absorption technique, the light absorption coefficients $\left(\sigma_{\mathrm{ap}}\right)$ at all wavelengths were calculated by using the method presented by Collaud Coen et al. (2010), where the $C_{\text {ref fac- }}$ tor was set to be 4.26 according to the value from Cabauw $(\mathrm{CAB})$ station reported in the same paper. CAB station is located near populated and industrialized areas, which was to some extent similar to Hok Tsui station (near most of cities in the Pearl River Delta region). The reported average $C_{\text {ref }}$ value at $\mathrm{CAB}$ was $4.26 \pm 0.11$, and it varies from 2.60 to 4.75 (Collaud Coen et al., 2010). There was no MAAP (Multi-Angle Absorption Photometer) or any other reference absorption instrument available, so determining $C_{\text {ref }}$ at Hok Tsui was not possible and the published mean $C_{\text {ref }}$ at CAB station was used. However, to present an upper estimate for $\sigma_{\text {ap }}$, the $C_{\text {ref }}$, calculated as 3.51 for the clean marine site of Mace Head (MHD); Collaud Coen et al., 2010), was also used and the respective average $\sigma_{\text {ap }}$ and SSA are presented in the discussions. Since the $C_{\text {ref }}$ is responsible for the largest uncertainty in the calculation of $\sigma_{\text {ap }}$ (Collaud Coen et al., 2010) we did not make further uncertain analyses by using the uncertainties related to the other factors within the algorithm. Absorption coefficients were presented under standard temperature and pressure (STP; $273.15 \mathrm{~K}, 1013 \mathrm{hPa}$ ). Measured BC concentrations were corrected following the algorithm presented by Virkkula et al. (2007).

\subsection{Scattering measurement}

Light-scattering coefficients $\left(\sigma_{\mathrm{sp}}\right)$ at wavelength of 450,550 and $700 \mathrm{~nm}$ were measured using an integrating nephelometer (model 3563, TSI Inc, St. Paul, MN, USA). The averaging time was set to $5 \mathrm{~min}$. Calibration was conducted once a month using $\mathrm{CO}_{2}$ and filtered air as described in the user manual. An internal heater was used to maintain a moderate relative humidity during measurement. Raw $\sigma_{\mathrm{sp}}$ data were corrected for truncation errors following the method from Anderson and Ogren, (1998), where the scattering coefficients were determined by calculating the Ångström exponents from uncorrected scattering coefficients and the correction factors with no-cut inlet. Scattering coefficients were then corrected to STP using pressure and temperature readings from the nephelometer.

The $\sigma_{\mathrm{sp}}$ and $\sigma_{\mathrm{ap}}$ data were used for calculating SSA as $\mathrm{SSA}=\sigma_{\mathrm{sp}} /\left(\sigma_{\mathrm{sp}}+\sigma_{\mathrm{ap}}\right)$. The nephelometer took its sample from a total suspended particle inlet (TSP) but the Aethalometer through a $\mathrm{PM}_{2.5}$ inlet, so it may seem somewhat uncertain which size range the SSA represents. However, $\mathrm{BC}$ is the most important light-absorbing constituent in aerosol particles and it is well known that it is in submicron size range. In larger particles there might be some light-absorbing dust particles, but their contribution at this site can be considered to be negligible. Therefore it is reasonable to claim that the absorption coefficients derived from the aethalometer data represent absorption in the full TSP size 
range even if there was a $\mathrm{PM}_{2.5}$ inlet for the Aethalometer. Since the scattering coefficients were measured after a TSP inlet, it is also reasonable to say that the SSA represents that of TSP.

\subsection{Particle size measurement and the use of the size distributions}

An Ultrafine Particle Monitor (UFPM, model 3031, TSI Inc.) was used to measure the number size distribution of particles in the size range of 20 to $800 \mathrm{~nm}$ with six size bins of mobility diameter: $20-30,30-50,50-70,70-100,100$ 200 , and $200-800 \mathrm{~nm}$. The operating principle of a UFPM is based on the diffusion charging of particles, followed by size segregation within a differential mobility analyzer (DMA) and the detection of the aerosol via a sensitive electrometer. The UFPM was equipped with a model 3031200 environmental sampling system. The sample inlet was placed $2.0 \mathrm{~m}$ above the ground. Ambient air was continuously drawn through a size selective $\mathrm{PM}_{10}$ inlet at a standard flow rate of 16.7 $\mathrm{L} \mathrm{min}^{-1}$. The sample then passed through a $\mathrm{PM}_{1} \mathrm{cy}-$ clone to remove larger particles. The main sample stream was subsampled into the UFP at a flow rate of $5 \mathrm{~L} \mathrm{~min}^{-1}$. A Nafion dryer was installed upstream of the UFP to ensure proper conditioning of the aerosol and to minimize effects due to water vapor. The remaining $11.7 \mathrm{~L} \mathrm{~min}^{-1}$ of makeup air, drawn through a vacuum pump and exhausted, was routed through the Nafion dryer as purge air. The averaging time was set to $15 \mathrm{~min}$.

The total mass concentrations of particles with a mobility diameter less than $800 \mathrm{~nm}$ were calculated using the following equation:

$\mathrm{PM}_{1}=\sum_{i=1}^{n} N_{i} \rho_{i} \frac{\pi}{6} D_{p, i}^{3}$,

where $N_{i}$ is the number concentration in each size bin, $\rho_{i}$ is the density of particles assumed to be $1.7 \mathrm{~g} \mathrm{~cm}^{-3}$, and $D_{p, i}$ is the geometric mean of the upper and lower limit diameter in each size bin.

For spherical particles the aerodynamic diameter $\left(D_{\mathrm{a}}\right)$ is calculated from the mobility diameter $\left(D_{\mathrm{m}}\right)$ as $D_{\mathrm{a}}=D_{\mathrm{m}} \sqrt{\rho_{\mathrm{p}} / \rho_{0}}$, where $\rho_{\mathrm{p}}$ is the density of the particle and $\rho_{o} \mathrm{i}$ s the density of water. For $D_{\mathrm{m}}=0.8 \mu \mathrm{m}$ and $\rho_{\mathrm{p}}=1.7 \mathrm{~g} \mathrm{~cm}^{-3}$, this yields $D_{\mathrm{a}}=1.0 \mu \mathrm{m}$. In the results, therefore, the mass concentration calculated from the number size distributions was denoted as $\mathrm{PM}_{1}$.

The size distributions were used for calculating scattering coefficients from the following equation:

$\sigma_{\mathrm{sp}}(\lambda)=\int Q_{\mathrm{sp}}\left(\lambda, D_{\mathrm{p}}, m\right) \frac{\pi D_{\mathrm{p}}^{2}}{4} n\left(D_{\mathrm{p}}\right) \mathrm{d} D_{\mathrm{p}}$,

where the scattering efficiencies $\left(Q_{\mathrm{sp}}\right)$ were calculated by using the BHMIE code (Bohren and Huffman, 1983). We assumed that the $D_{\mathrm{p}}$ of each particle is equal to the geometric mean of the upper and lower limit diameter in its size bin for modeling, and the aerosol is ammonium sulfate with the refractive index $m=m_{\mathrm{r}}=1.52$ (Chamaillard et al., 2006). The refractive index used in the modeling could, in principle, be varied and iterated until the measured and modeled scattering coefficients match, as was done, for example, by Virkkula et al. (2011). However, due to the different size ranges and low number of size bins of the size distributions, this kind of iteration is not reasonable for the data in this work.

Both the $\mathrm{PM}_{1}$ and the $\sigma_{\mathrm{sp}}$ calculated from the number size distributions have uncertainties due to the uncertainties of the UFPM. The first is the wide range of particle diameters within the size bins and the use of the geometric mean of the bin limits for the whole bin. This yields the highest uncertainty for the bin that measures particles in the size range 200-800 $\mathrm{nm}$ that can easily be calculated assuming all particles in that size range were $800 \mathrm{~nm}$ instead of the geometric mean $400 \mathrm{~nm}$. This calculation is theoretical in the real atmosphere, however, and yields unrealistically high uncertainties and will not be analyzed further. Another source of uncertainty is related to the instrument itself. Hillemann et al. (2014) found that the number of concentrations measured by UFPM are typically within a range of $\pm 20 \%$ from the reference values measured with a scanning mobility particle sizer (SMPS). Also, Gómez-Moreno et al. (2015) compared the UFPM with an SMPS and found that the size distributions measured by UFPM and SMPS were similar in the sense that the peak concentrations were observed at the same size. In the same study it was also observed that in the size channels corresponding to particle diameters $<100 \mathrm{~nm}$ the UFP overestimated the number concentrations and in the two largest channels it underestimated the number concentrations. These are the channels that measure the particles that have the highest mass and that scatter light most efficiently. It may therefore be argued that both the $\mathrm{PM}_{1}$ and the modeled $\sigma_{\mathrm{sp}}$ are underestimated.

It was mentioned above that the $\mathrm{PM}_{1}$ concentrations were calculated by using the density of $1.7 \mathrm{~g} \mathrm{~cm}^{-3}$, which deserves reasoning. The densities of major inorganic aerosol compounds such as ammonium sulfate and sodium chloride are 1.76 and $2.165 \mathrm{~g} \mathrm{~cm}^{-3}$ (e.g., Tang, 1996). Zhang et al. (2008) estimated that the density of sulfuric acid-coated soot is $1.7 \mathrm{~g} \mathrm{~cm}^{-3}$. Ambient aerosols contain many unknown compounds (such as organics) and also some water (even after drying to $\mathrm{RH}<50 \%$ ). Therefore, densities of ambient aerosols can vary within a certain range based on their compositions. Densities of real atmospheric aerosols have been measured in several campaigns. Quinn et al. (2001) determined aerosol densities on a cruise across the Atlantic Ocean. The density of submicron aerosols, averaged from observations at very different regions, was $1.73 \pm 0.24 \mathrm{~g} \mathrm{~cm}^{-3}$. Pitz et al. (2003) determined the mean apparent particle density of $1.6 \pm 0.5 \mathrm{~g} \mathrm{~cm}^{-3}$ for urban aerosol. Saarikoski et al. (2005) found that at a boreal forest site the average density was $1.66 \pm 0.13 \mathrm{~g} \mathrm{~cm}^{-3}$. Based on these publications it is reason- 
able to use the density value of $1.7 \mathrm{~g} \mathrm{~cm}^{-3}$ for the estimation of aerosol mass concentration from the number size distributions of particles smaller than $800 \mathrm{~nm}$ of the mobility diameter. It has to be noted. However, there is uncertanty, in the aerosol mass concentration since the density was not measured at this site.

\subsection{Supporting measurements}

CO data were used to help analyze aerosol sources since they typically originate from incomplete combustion like BC. Hourly mixing ratios of carbon monoxide were measured with a nondispersive infrared absorption instrument (Teledyne API model 300) at Hok Tsui station.

In addition to the measurements at the HT station, the following supporting data measured at two nearby sites were used in the analyses. $\mathrm{SO}_{2}$ is the precursor of sulfate, the most important light-scattering constituent and it is also one of the major pollutants of ship emission. $\mathrm{PM}_{2.5}$ concentrations can be used for a semi-quantitative quality check of the aerosol mass concentrations calculated from the size distributions. Hourly $\mathrm{SO}_{2}$ and $\mathrm{PM}_{2.5}$ concentrations at Eastern Station (about $7 \mathrm{~km}$ away from HT station, the location shown in Fig. 1b), were downloaded from the open-access dataset from the website of the Hong Kong Environmental Protection Department (HKEPD).

The hourly averaged meteorological parameters, including air temperature, relative humidity ( $\mathrm{RH})$, wind direction, wind speed, and precipitation were obtained from the dataset in the HKEPD in which meteorological data from the nearest meteorological station (Waglan Island, WGL) were used for analyzing this paper. The location of the WGL station is shown in Fig. 1b.

\subsection{Backward Lagrangian particle dispersion modeling (LPDM)}

Transport and dispersion simulations were conducted using a Lagrangian particle dispersion modeling (LPDM) following the method developed by Ding et al., (2013). LPDM was conducted by using the Hybrid Single-Particle Lagrangian Integrated Trajectory (HYSPLIT) model, developed in the Air Resource Laboratory (ARL) of the US National Oceanic and Atmospheric Administration (Draxler and Hess, 1998; Stein et al., 2015). In each simulation, particles were released at a height of $100 \mathrm{~m}$ above the ground level at the site and went backward in time for a 7-day period. LPDM calculations were driven with GDAS (Global Data Assimilation System) data (http://ready.arl.noaa.gov/HYSPLIT.php). Particle positions were calculated in each hour and gridded concentrations were in a spatial resolution of $0.01^{\circ}$ latitude by $0.01^{\circ}$ longitude.

Knowing the transport characteristics of air masses, the next step was to explore the source profile of light absorbing particles affecting the regional aerosol optical proper-
Table 1. Statistical summary of data measured at Hok Tsui station. Scattering coefficients $\left(\sigma_{\mathrm{sp}}\right)$ and absorption coefficients $\left(\sigma_{\text {ap }}\right)$ at $\lambda=550 \mathrm{~nm}$ are corrected to STP $(1013 \mathrm{mbar}, 273.15 \mathrm{~K})$, Ångström exponents of scattering and absorption (SAE, AAE), single-scattering albedo (SSA), total particle number concentration, $\left(N_{\text {total }}\right)$ geometric mean diameter $(\mathrm{GMD})$, and $\left.\mathrm{PM}_{1}\right)$.

\begin{tabular}{lrrrrrr}
\hline & & \multicolumn{5}{c}{ Percentile } \\
\cline { 3 - 7 } & AVG $\pm \mathrm{SD}$ & 5 & 25 & 50 & 75 & 95 \\
\hline$\sigma_{\text {ap }, 550 \mathrm{~nm}\left(\mathrm{Mm}^{-1}\right)}$ & $8.3 \pm 6.1$ & 2.2 & 4.0 & 6.6 & 11.0 & 19.3 \\
$\sigma_{\text {sp }, 550 \mathrm{~nm}\left(\mathrm{Mm}^{-1}\right)}$ & $151 \pm 100$ & 23 & 75 & 134 & 206 & 331 \\
$\mathrm{SSA}(550 \mathrm{~nm})$ & $0.93 \pm 0.05$ & 0.84 & 0.92 & 0.94 & 0.96 & 0.98 \\
$\mathrm{BC}\left(\mu \mathrm{g} \mathrm{m}^{-3}\right)$ & $1.4 \pm 1.1$ & 0.2 & 0.6 & 1.2 & 1.9 & 3.4 \\
$\mathrm{CO}(\mathrm{ppbv})$ & $272 \pm 185$ & 59 & 109 & 242 & 373 & 623 \\
$\mathrm{AAE}$ & $1.0 \pm 0.2$ & 0.5 & 0.9 & 1.1 & 1.2 & 1.4 \\
$\mathrm{SAE}$ & $1.4 \pm 0.4$ & 0.6 & 1.1 & 1.4 & 1.6 & 2.0 \\
$N_{\text {total }}\left(\mathrm{cm}^{-3}\right)$ & $7790 \pm 4300$ & 2980 & 5060 & 6830 & 9410 & 15710 \\
$\mathrm{GMD}(\mathrm{nm})$ & $67 \pm 17$ & 43 & 55 & 65 & 77 & 98 \\
$\mathrm{PM}_{1}\left(\mu \mathrm{g} \mathrm{m}^{-3}\right)$ & $22 \pm 19$ & 3 & 10 & 18 & 29 & 55 \\
\hline
\end{tabular}

ties in Hong Kong. Since BC is the most significant lightabsorbing constituent of aerosols, the PSC of BC to observed air masses was calculated using the MIX Asian emission inventory ( $\mathrm{Li}$ et al., 2017) together with LPDM results. The MIX emission inventory has a horizontal grid resolution of $0.25^{\circ} \times 0.25^{\circ}$ in longitude and latitude and it is considered the anthropogenic emissions from transportation, residential, industry, and power generation in continental area. In each grid cell, the emission rate was multiplied by the footprint retroplume, and the sum of this potential source contribution of all grid cells can provide the total $\mathrm{BC}$ concentration resulting from emissions during a certain period (Ding et al., 2013). The maps of averaged source contribution profile of $\mathrm{BC}$ in different seasons were calculated covering $70-140^{\circ}$ in longitude and $0-50^{\circ}$ in latitude. This method to calculate the PSC of target pollutants has been adopted in a previous study by Ding et al. (2013). The major advantage of this method is that it captures the potential contribution of target pollutants to the receptor due to the transport of air mass containing the information of anthropogenic emissions.

In this study, the MIX emission inventory provided relatively high spatial resolution of $\mathrm{BC}$ emission rates, considering its major anthropogenic sources in China and nearby Asian countries. However, marine emission is not included in the MIX database. To investigate the possible influence of marine sources, like ship emissions, on the observed aerosol concentrations at this coastal site, we used the observed aerosol concentrations together with the LPDM footprint. We used the following concentration-weighted equation to calculate the potential source contribution from each grid cell:

$A_{x(i, j)}=\frac{\sum_{t=1}^{n}\left(x_{t} \cdot R_{t(i, j)}\right)}{\sum_{t=1}^{n} R_{t(i, j)}}$, 
(a)

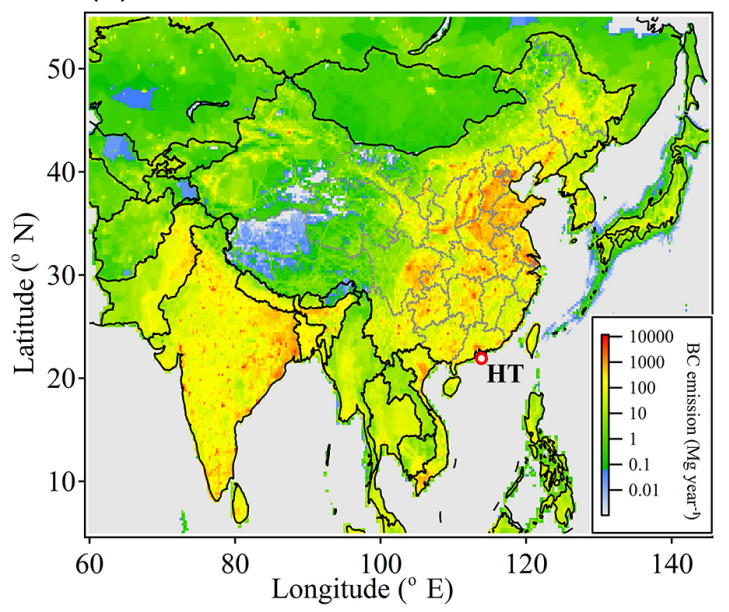

(b)

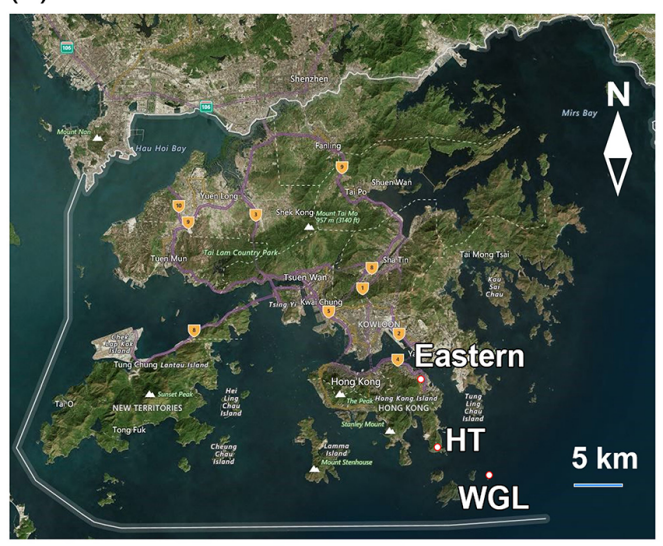

(c)
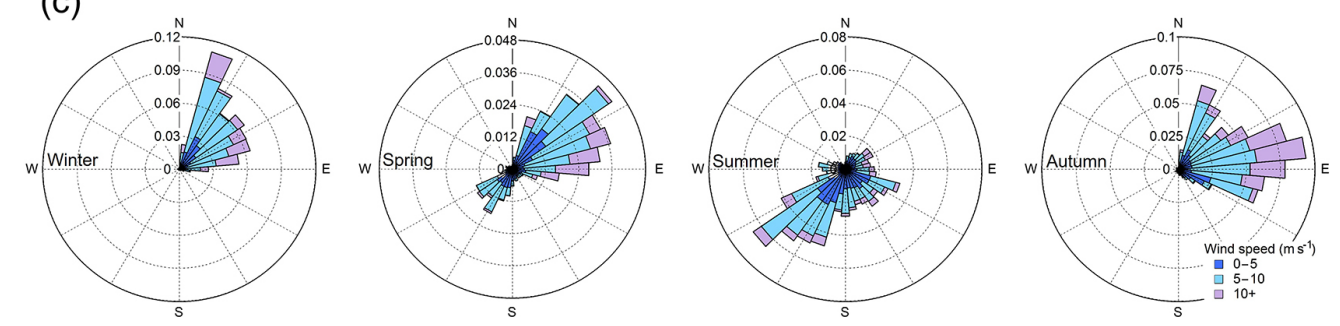

Figure 1. (a) Map showing the location of Hok Tsui (HT) monitoring station with emission inventory in Asia. (b) Locations of monitoring stations mentioned in this paper and (c) wind rose plot at WGL in Hong Kong.

where $x$ is the selected optical property or other parameters, and we chose $\sigma_{\mathrm{ap}}, \sigma_{\mathrm{sp}}$ and $\mathrm{PM}_{1}$ in this study. $R$ represents the retroplume with 3-day backward time, while $t$ is the time step and $n$ is the total number of the time steps. The interpretation of Eq. (3) is that it shows the average value of the property $x$ observed at the receiving site when air masses have come from over grid cell $i, j$. The method is analogous to that presented by Stohl et al. (1996) and the concentration-weighted trajectory (CWT) methods reviewed by Cheng et al. (2015). The major difference is that in the present approach, the footprints were used instead of single trajectories for each time step.

\section{Results and discussions}

\subsection{Aerosol optical properties and their relationships with particle size}

\subsubsection{Overall results of aerosol optical properties and related parameters}

Table 1 shows a basic statistical summary of all measured parameters. The light absorption coefficients at $\lambda=550 \mathrm{~nm}$ were interpolated between the $\sigma_{\text {ap }}$ at 520 and $590 \mathrm{~nm}$. The mean absorption and scattering coefficients at $\lambda=550 \mathrm{~nm}$ during the whole measurement period were $8.3 \pm 6.1$ and
$151 \pm 100 \mathrm{Mm}^{-1}$, respectively. As mentioned in the methods, the above-mentioned $\sigma_{\text {ap }}$ was calculated by using the $C_{\text {ref }}$ of CAB. If, instead, we use the $C_{\text {ref }}$ of MHD, $\sigma_{\mathrm{ap}}=10.1 \pm 6.1$, which may be considered as an upper estimate. Table 2 summarizes the light-scattering and absorption coefficients and single-scattering albedos observed in this study and in selected other studies using comparable instruments (Man and Shih, 2001; Xu et al., 2002; Yan et al., 2008). On average, the $\sigma_{\text {ap }}$ was lower than that measured at Lin'an regional background station in the rural area of the Yangtze River Delta region (Xu et al., 2002). Compared to the value measured at Hok Tsui 15 years ago, $\sigma_{\mathrm{ap}}$ was lower than that observed in Hok Tsui, from November 1997 to February 1999 (Man and Shih, 2001). Being the most significant light-absorbing constituent of aerosols, a similar decrease of $\mathrm{BC}$ concentration was also found. Table 3 presents the mean $\mathrm{BC}$ mass concentrations reported in other comparable studies. The overall average of $\mathrm{BC}$ mass concentrations in this study was $1.4 \pm 1.1 \mathrm{\mu g} \mathrm{m}^{-3}$ (Table 1), which was lower than the values observed at same site in 2004-2005 (with a mean of $2.4 \mathrm{\mu g} \mathrm{m}^{-3}$ using a AE-42 Aethalometer; Cheng et al., 2006a). A decreasing trend of $B C$ concentration was found at the Panyu station in the PRD region with a decreasing rate of approximately $1 \mu \mathrm{g} \mathrm{m}^{-3}$ per year from 2004 to 2007 (Wu et al., 2009). Compared to the other rural sites in South China, $\mathrm{BC}$ levels in Hok Tsui station were lower than the concentra- 
Table 2. Summarization of aerosol light-scattering coefficients, absorption coefficients and single-scattering albedo observed in this study and reported in other studies.

\begin{tabular}{|c|c|c|c|c|c|c|}
\hline Site & Period & $\sigma_{\mathrm{ap}}$ & $\sigma_{\mathrm{sp}}$ & SSA & Instrumentation & References \\
\hline $\begin{array}{l}\text { Hok Tsui, } \\
\text { Hong Kong } \\
\text { (rural, coastal) }\end{array}$ & Feb 2012-Feb 2015 & $8.3 \pm 6.1$ & $151 \pm 100$ & $0.93 \pm 0.05$ & $\begin{array}{l}\text { AE31, Magee Scientific } \\
\text { Nephelometer, TSI, Inc. }\end{array}$ & This work \\
\hline Cape D'Aguilar & Nov 1997-Feb 1998 & 25.72 & 64.77 & & PSAP, Radiance Research & Man and Shih (2001) \\
\hline (Hok Tsui), & Mar-Apr 1998 & 15.79 & 38.65 & & Nephelometer, & \\
\hline Hong Kong & May-Aug 1998 & 6.03 & 8.71 & & Radiance Research & \\
\hline (rural, coastal) & Sep-Oct 1998 & 18.98 & 70.91 & & & \\
\hline & Nov 1998-Feb 1999 & 31.22 & 96.75 & & & \\
\hline $\begin{array}{l}\text { Xinken, PRD, } \\
\text { China (non-urban, } \\
\text { regionally polluted) }\end{array}$ & Oct-Nov 2004 & $70 \pm 42$ & $333 \pm 137$ & $0.83 \pm 0.05$ & $\begin{array}{l}\text { MAAP, Thermo, Inc. } \\
\text { Nephelometer, TSI, Inc. }\end{array}$ & Cheng et al. (2008) \\
\hline $\begin{array}{l}\text { Shangdianzi, } \\
\text { China (rural) }\end{array}$ & Sep 2003-Jan 2005 & $17.54 \pm 13.44$ & $174.6 \pm 189.1$ & $0.88 \pm 0.05$ & $\begin{array}{l}\text { AE31, Magee Scientific } \\
\text { Nephelometer, EcoTech }\end{array}$ & Yan et al., (2008) \\
\hline $\begin{array}{l}\text { Lin’an, } \\
\text { China (rural) }\end{array}$ & Nov 1999 & $23 \pm 14$ & $353 \pm 202$ & $0.93 \pm 0.04$ & $\begin{array}{l}\text { PSAP, Radiance Research } \\
\text { Nephelometer, Radiance Research }\end{array}$ & Xu et al. (2002) \\
\hline $\begin{array}{l}\text { Granada, } \\
\text { Spain (urban) }\end{array}$ & Dec 2005-Nov 2007 & $21 \pm 10$ & $60 \pm 30$ & $0.68 \pm 0.07$ & $\begin{array}{l}\text { MAAP, Thermo, Inc. } \\
\text { Nephelometer, TSI, Inc. }\end{array}$ & Lyamani et al., (2010) \\
\hline $\begin{array}{l}\text { Alomar station, } \\
\text { Norway (background, } \\
\text { coastal) }\end{array}$ & Jun-Aug 2008 & $0.40 \pm 0.27$ & $5.41 \pm 3.55$ & $0.91 \pm 0.05$ & $\begin{array}{l}\text { PSAP, Radiance Research } \\
\text { Nephelometer, TSI, Inc. }\end{array}$ & Mogo et al. (2012) \\
\hline
\end{tabular}

Table 3. Comparison of mean concentration of $\mathrm{BC}$ with other studies.

\begin{tabular}{|c|c|c|c|c|c|c|}
\hline Site & Environment & Period & Inlet & $\mathrm{BC}\left(\mu \mathrm{g} \mathrm{m}^{-3}\right)$ & Instrumentation & References \\
\hline $\begin{array}{l}\text { Hok Tsui, } \\
\text { Hong Kong }\end{array}$ & Rural, coastal & Feb 2012-Feb 2015 & $\mathrm{PM}_{2.5}$ & $1.4 \pm 1.1$ & $\begin{array}{l}\text { AE31, Magee } \\
\text { Scientific }\end{array}$ & This work \\
\hline $\begin{array}{l}\text { Cape D'Aguilar } \\
\text { (Hok Tsui), } \\
\text { Hong Kong }\end{array}$ & Rural, coastal & Jun 2004-May 2005 & $\mathrm{PM}_{2.5}$ & $2.4 \pm 1.8$ & $\begin{array}{l}\text { AE42, Magee } \\
\text { Scientific }\end{array}$ & Cheng et al. (2006a) \\
\hline $\begin{array}{l}\text { Yongxing Island, } \\
\text { China }\end{array}$ & $\begin{array}{l}\text { Oceanic rural, } \\
\text { (South China Sea) }\end{array}$ & May-Jun 2008 & $\mathrm{PM}_{2.5}$ & $\begin{array}{r}0.54 \text { (rainy season) } \\
0.67 \text { (dry season) }\end{array}$ & $\begin{array}{l}\text { Aethalometer, } \\
\text { Magee Scientific }\end{array}$ & Yu et al. (2013) \\
\hline $\begin{array}{l}\text { Maofengshan, } \\
\text { China }\end{array}$ & Rural, PRD & May-Jun 2008 & $\mathrm{PM}_{10}$ & $\begin{array}{r}2.62 \text { (rainy season) } \\
2.88 \text { (dry season) }\end{array}$ & $\begin{array}{l}\text { Aethalometer, } \\
\text { Magee Scientific }\end{array}$ & Yu et al. (2013) \\
\hline Toulon, France & Semi-urban, coastal & Jun 2005-Oct 2006 & $\mathrm{PM}_{2.5}$ & $\begin{array}{r}0.95 \text { (winter) } \\
0.45 \text { (summer) }\end{array}$ & $\begin{array}{l}\text { AE31, } \\
\text { Magee Scientific }\end{array}$ & Saha and Despiau (2009) \\
\hline $\begin{array}{l}\text { Hyytiälä, } \\
\text { Finland }\end{array}$ & Boreal forest & Dec 2004-Dec 2008 & $\mathrm{PM}_{2.5}$ & $0.32 \pm 0.34$ & $\begin{array}{l}\text { AE31, } \\
\text { Magee Scientific }\end{array}$ & Hyvarinen et al. (2011) \\
\hline $\begin{array}{l}\text { Voerde-Spellen, } \\
\text { Germany }\end{array}$ & Rural & Sep-Oct 1997 & $\mathrm{PM}_{2.5}$ & $0.8 \pm 0.3$ & AE-10 IM, G1V & Kuhlbusch et al. (2001) \\
\hline $\begin{array}{l}\text { Preila, } \\
\text { Lithuania }\end{array}$ & Rural, coastal & Mar-Apr 2002 & $\mathrm{PM}_{2.5}$ & 0.84 & $\begin{array}{l}\text { AE40, } \\
\text { Magee Scientific }\end{array}$ & Andriejauskienė (2008) \\
\hline
\end{tabular}

tions measured at a rural site in the center of the PRD region, yet higher than those on Yongxing Island, an oceanic rural site in the middle of the South China Sea (Yu et al., 2013). $\mathrm{BC}$ concentrations were also higher than those measured in European coastal stations (Saha and Despiau, 2009; Andriejauskienè, 2008). The $\sigma_{\mathrm{sp}}$ was comparable to that obtained at Shangdianzi station in a suburb of Beijing, but much higher than the value at Hok Tsui station measured a decade ago (Yan et al., 2008; Man and Shih, 2001). The overall average $\mathrm{SSA}_{550 \mathrm{~nm}}$ was $0.93 \pm 0.05$, which was comparable to that in a rural station, Lin'an, China (Xu et al., 2002) but higher than those measured in a suburban station in northern China (Mean SSA $525 \mathrm{~nm}=0.88$; Yan et al., 2008). In addition, as above with $\sigma_{\text {ap }}$, a lower estimate for $\mathrm{SSA}=0.92 \pm 0.05$ can be obtained by using the $C_{\text {ref }}$ of MHD in the calculations. This shows that even by changing the $C_{\text {ref }}$ by $\sim 20 \%$ the SSA is very high, which is reasonable at a site at the sea. CO mixing ratios in Hok Tsui station were comparable to those measured at the same site in 1994-1996 (Lam et al., 2001).

\subsubsection{Temporal variations and overall characteristics}

The seasonal cycles of target parameters were analyzed based on hourly-averaged data classified as four seasons: winter (December-February), spring (March-May), summer (June-August), and autumn (September-November). Seasonal averaged values of selected parameters are listed in 
Table 4. Summary of seasonal average value of target pollutants.

\begin{tabular}{|c|c|c|c|c|c|c|c|c|}
\hline & \multicolumn{2}{|c|}{ Winter } & \multicolumn{2}{|c|}{ Spring } & \multicolumn{2}{|c|}{ Summer } & \multicolumn{2}{|c|}{ Autumn } \\
\hline & $\mathrm{AVG} \pm \mathrm{SD}$ & MED & $\mathrm{AVG} \pm \mathrm{SD}$ & MED & $\mathrm{AVG} \pm \mathrm{SD}$ & MED & $\mathrm{AVG} \pm \mathrm{SD}$ & MED \\
\hline$\sigma_{\mathrm{ap}, 550 \mathrm{~nm}}\left(\mathrm{Mm}^{-1}\right)$ & $10.9 \pm 7.1$ & 9.6 & $7.5 \pm 4.8$ & 6.4 & $5.5 \pm 5.8$ & 3.8 & $7.4 \pm 4.5$ & 6.3 \\
\hline$\sigma_{\mathrm{sp}, 550 \mathrm{~nm}}\left(\mathrm{Mm}^{-1}\right)$ & $193 \pm 102$ & 176 & $148 \pm 89$ & 133 & $64 \pm 62$ & 49 & $140 \pm 82$ & 130 \\
\hline $\mathrm{SSA}(550 \mathrm{~nm})$ & $0.94 \pm 0.03$ & 0.95 & $0.93 \pm 0.05$ & 0.95 & $0.90 \pm 0.06$ & 0.92 & $0.94 \pm 0.03$ & 0.95 \\
\hline $\mathrm{BC}\left(\mu \mathrm{g} \mathrm{m}^{-3}\right)$ & $2.0 \pm 1.2$ & 1.8 & $1.3 \pm 1.0$ & 1.2 & $0.9 \pm 1.1$ & 0.6 & $1.5 \pm 0.9$ & 1.4 \\
\hline $\mathrm{CO}$ (ppbv) & $459 \pm 186$ & 423 & $275 \pm 154$ & 262 & $117 \pm 84$ & 91 & $270 \pm 134$ & 252 \\
\hline $\mathrm{AAE}$ & $1.1 \pm 0.2$ & 1.1 & $1.0 \pm 0.3$ & 1.0 & $0.7 \pm 0.4$ & 0.7 & $0.9 \pm 0.3$ & 0.8 \\
\hline SAE & $1.3 \pm 0.3$ & 1.3 & $1.2 \pm 0.5$ & 1.2 & $1.4 \pm 0.6$ & 1.5 & $1.7 \pm 0.4$ & 1.8 \\
\hline$N_{\text {total }}\left(\mathrm{cm}^{-3}\right)$ & $7690 \pm 3821$ & 6768 & $8620 \pm 4868$ & 7540 & $7003 \pm 4460$ & 5943 & $7808 \pm 3970$ & 7077 \\
\hline GMD (nm) & $72 \pm 17$ & 70 & $68 \pm 15$ & 66 & $58 \pm 17$ & 54 & $69 \pm 17$ & 68 \\
\hline $\mathrm{PM}_{1}\left(\mu \mathrm{g} \mathrm{m}^{-3}\right)$ & $27 \pm 19$ & 22 & $25 \pm 19$ & 21 & $13 \pm 20$ & 7 & $22 \pm 14$ & 19 \\
\hline
\end{tabular}
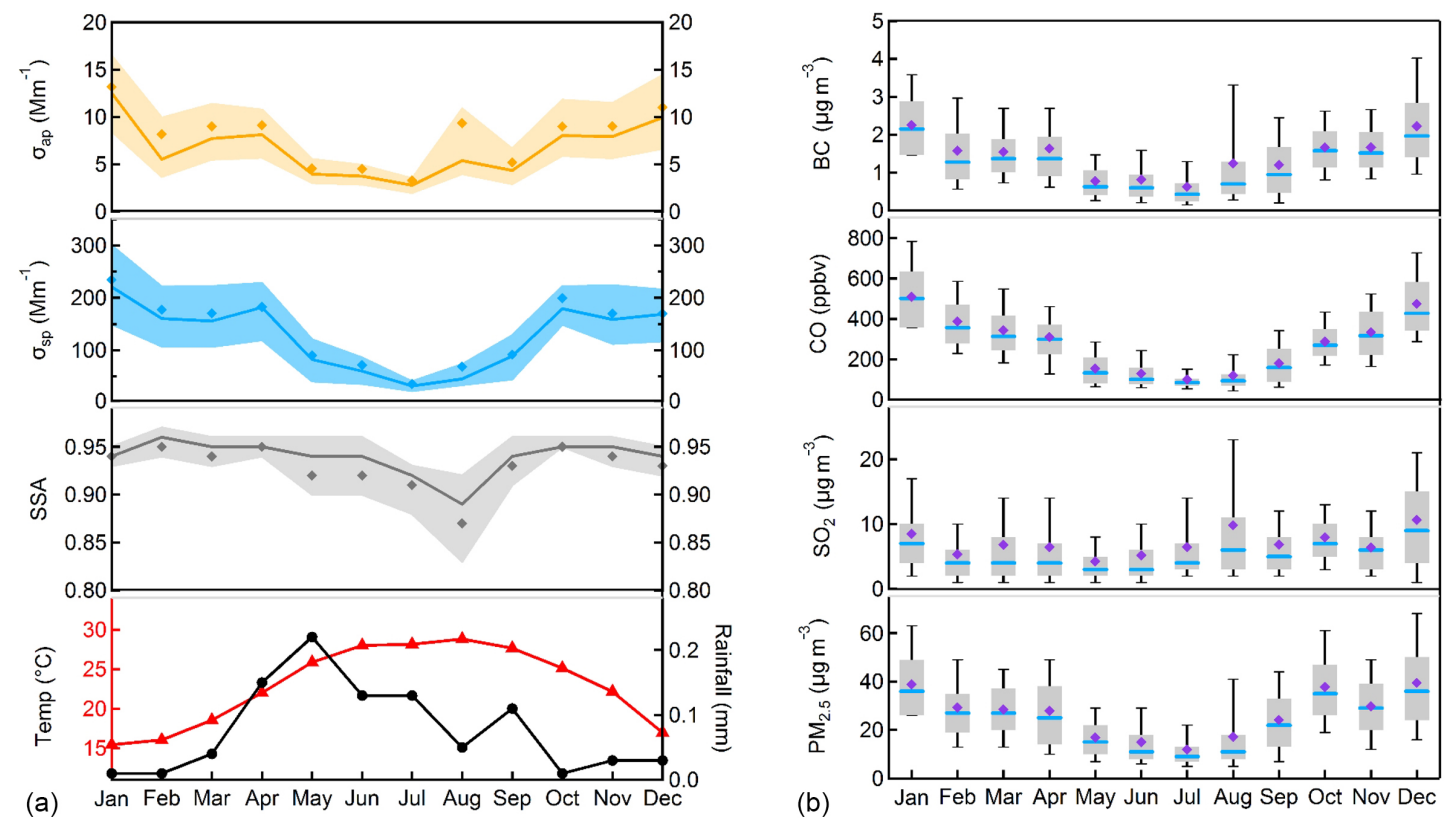

Figure 2. (a) Seasonal cycle of scattering coefficient, $\sigma_{\mathrm{sp}}$; absorption coefficient, $\sigma_{\mathrm{ap}}$; single-scattering albedo; SSA; temperature; and precipitation; where bold solid lines represent median values, diamonds show the monthly averages, and thin solid lines are percentiles of 75 and $25 \%$. (b) Seasonal cycles of $\mathrm{BC}, \mathrm{CO}, \mathrm{SO}_{2}$, and $\mathrm{PM}_{2.5}$ concentrations, where blue solid lines represent median values, diamonds show the monthly averages, the boxes are 25th and 75th percentiles, and the thin bars represent 10th and 90th percentiles.

Table 4. The highest $\sigma_{\mathrm{ap}}$ and $\sigma_{\mathrm{sp}}$ values were observed in winter (10.9 \pm 7.1 and $193.5 \pm 102 \mathrm{Mm}^{-1}$, respectively), which were more than twice that of summer. A similar pattern was observed in a previous study in Hong Kong in 1997-1999 (Man and Shih, 2001). Compared with other rural/background sites, the average $\mathrm{SSA}_{550 \mathrm{~nm}}$ at Hok Tsui was $0.94 \pm 0.03$ during autumn, which was higher than that measured at Xinken, PRD, China, in the same season $(0.83 \pm 0.05)$, while this value was $0.90 \pm 0.06$ in summer, which was slightly lower than that observed at a coastal station in Norway ;also in summer $(0.91 \pm 0.05$, Mogo et al., 2012).
Figure 2 presents the monthly variation of measured optical properties and meteorological parameters. A clear seasonal cycle of aerosol optical properties is shown with $\sigma_{\text {ap }}$ and $\sigma_{\mathrm{sp}}$, having peaked in January and reaching the lowest level in July. While it was lighter in winter, the aerosol was the darkest in summer, especially in August, with a seasonal mean SSA of 0.87. Averaged seasonal values of 1-SSA in 36 wind sectors are presented in Fig. 3a. These figures show the disparity of SSA from different wind directions. Overall, air plume coming from the southwest to the north (225$360^{\circ}$ ) had higher 1-SSA, i.e., lower SSA, than that from the east $\left(45-135^{\circ}\right)$. Ding et al. (2013) reported that the contribu- 

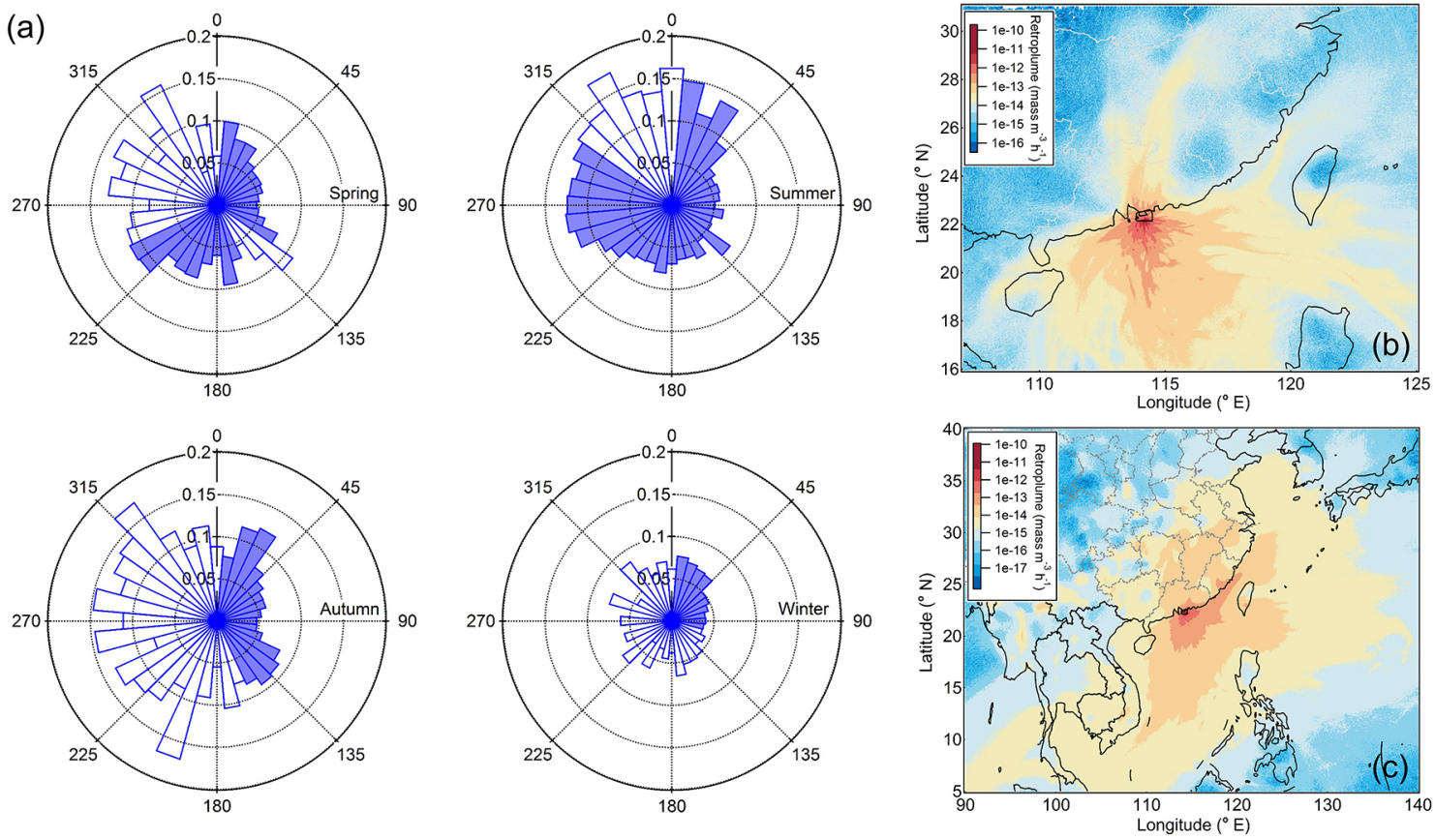

Figure 3. (a) Seasonal mean value of 1-SSA in 36 wind sectors during the whole period. (b) Map of averaged 7-day retroplume when SSA is below 0.9 compared with (c) averaged 7-day retroplume during the whole period.
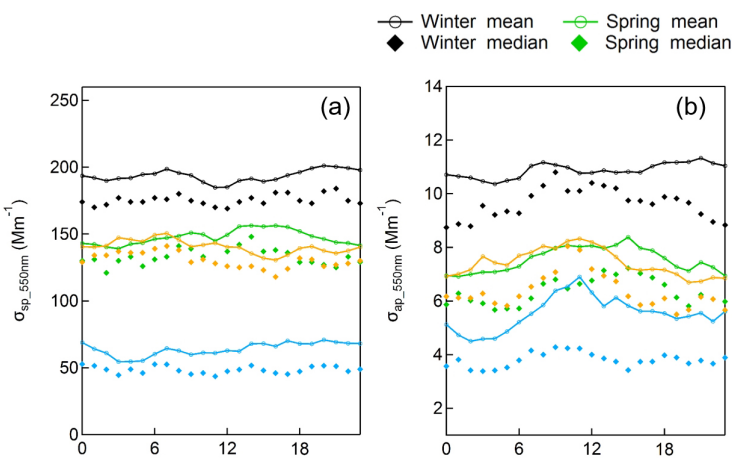

$$
\begin{aligned}
& - \text { Summer mean } \odot \text { Autumn mean } \\
& \text { Summer median }
\end{aligned}
$$
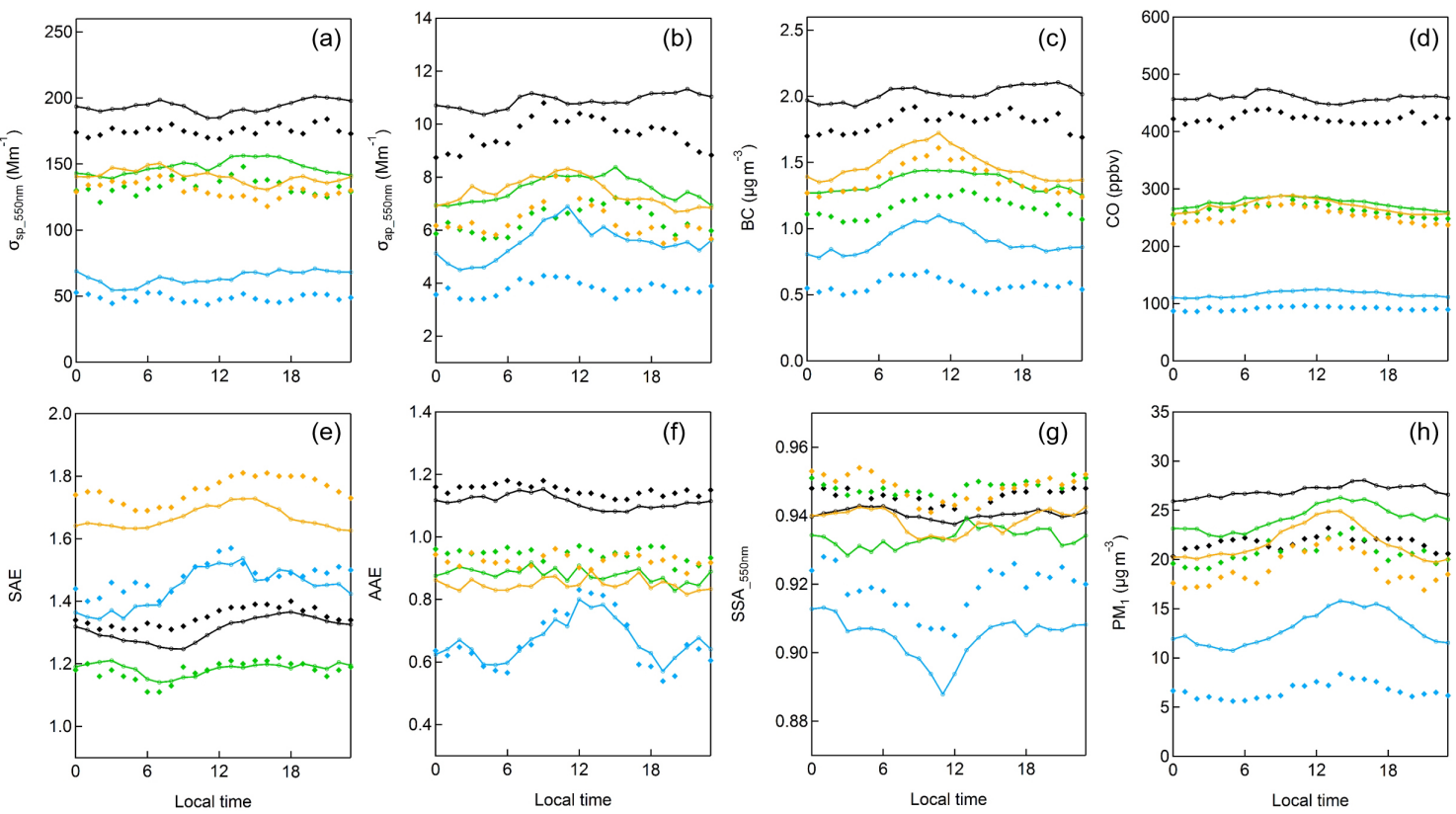

Figure 4. Averaged diurnal variations of (a) $\sigma_{\mathrm{sp}}$, (b) $\sigma_{\mathrm{ap}}$, (c) BC, (d) CO, (e) SAE, (f) AAE, (g) SSA, and (h) $\mathrm{PM}_{1}$ in four seasons.

tion of anthropogenic emissions from Guangdong and Hong Kong was the highest in August, which means more freshly emitted urban aerosols were brought to the monitoring station with lower SSA in this month (Cheng et al., 2008). The main synoptic process contributing to this kind of sub- regional transport is tropical cyclones. Ding et al. (2004) explained the mechanism of how these tropical cyclones influence the development of sea-land breeze and also explained further about sub-regional and urban air mass accumulation in the South China. Zhang et al. (2013) found an important 
influence of tropical cyclones in ozone and haze pollution in this region in summer, based on an analysis of 13-year data.

Another possible reason for the relatively low SSA in August is that the air mass came mainly from the southwest of the site (Fig. 1), a main waterway for ocean-going vessels in Hong Kong (Yau et al., 2012). These vessels emitted considerable amount of light-absorbing carbon from diesel engines during combustion. Similar pattern was also observed in the seasonal diagrams of $\mathrm{BC}, \mathrm{SO}_{2}, \mathrm{PM}_{2.5}$, and $\mathrm{CO}$, which are typical components of ship exhaust (Fig. 2, Hong Kong Air Pollutant Emission Inventory for 2013 from Hong Kong Environmental Protection Department: http://www.epd.gov.hk/ epd/english/environmentinhk/air/data/emission_inve.html).

Figure $3 \mathrm{~b}$ demonstrates the averaged 7-day retroplume of the times when SSA was lower than 0.9. Compared with the overall averaged 7-day retroplume during the whole measurement period (Fig. 3c), darker aerosols were mostly from two main types of regions in the vicinity: one was the nearby continental area with fresh polluted air masses from urban Hong Kong and neighboring PRD cities; another branch was from the ocean side. Fresh emission of passing ships or fast transport from southern Asia could lead to higher proportion of $\mathrm{BC}$ in the air plumes and thus caused lower SSA.

Figure 4 shows the diurnal cycles of $\sigma_{\mathrm{ap}}, \sigma_{\mathrm{sp}}, \mathrm{BC}, \mathrm{CO}$, and $\mathrm{PM}_{1}$ for four seasons. There was an increase in $\sigma_{\mathrm{ap}}$ after sunrise with a peak occurring before noontime. It might be associated with a combined effect of increased human activities and turbulence mixing in the boundary layer in the morning. This pattern was more significant in summer, although the pollution level was relatively low. This phenomenon supports the explanation of turbulent mixing from a middle or upper planetary boundary layer (PBL) because of a stronger vertical mixing in summer. The $\mathrm{PM}_{1}$ also showed a daytime maximum concentration but with the peak in the afternoon (Fig. 4c). For $\sigma_{\mathrm{sp}}$, morning peaks were not as significant as $\sigma_{\text {ap }}$. The decrease in $\sigma_{\text {ap }}$ in the early afternoon might be caused by a further development of PBL or mixing layer, in which the air pollutants experienced a substantial dilution, resulting in lower concentrations of pollutants at the ground surface. Diurnal variations and fluctuations of CO mixing ratios show a similar pattern with $\sigma_{\text {ap }}$ but a relatively smaller variability.

\subsubsection{Optical properties and their relationships with particle size}

Wavelength dependencies of aerosol light scattering and absorption are closely related to aerosol size and dominating aerosol types. To find out the difference of light absorbing materials, Fig. 5a displays the relationship of SSA with AAE, color-coded with a $\mathrm{BC}$ mass fraction of submicron particles $\left(\mathrm{PM}_{1}\right.$ was calculated from the particle number size distributions measured with the UFPM.) It shows that aerosols with high SSA had a lower BC fraction and that AAE varied greatly in the lower value region, indicating the dominance of scattering particles. Such air masses were likely of longer transport time and the $\mathrm{BC}$ aerosols had mixed well with lightscattering aerosols during transport. Contrarily, the low SSA values mostly occurred when AAE were closely distributed around 1.0 and in these cases $\mathrm{BC}$ took up a higher proportion (red dots in Fig. 5a), showing freshly emitted BC plumes.

Figure $5 \mathrm{~b}$ and $\mathrm{c}$ demonstrate the relationships between particle size and their scattering Ångström exponents as well as their darkness. It can be observed that SAE generally increased with decreasing SSA. Dark aerosols with low SSA were mostly small in size with low GMD but a high BC fraction. These small dark aerosols had higher SAE (1.5 to 2.0). The wide range of SAE was possibly due to the mixed control by continental aerosols and large sea-salt aerosols.

Figure 6 shows the scatter plot of $\sigma_{\mathrm{sp}}$ calculated using Eq. (2) versus the measured $\sigma_{\mathrm{sp}}$. The slope of $\sigma_{\mathrm{sp} \text {, submicron }} / \sigma_{\mathrm{sp} \text {, obs }}$ was 0.86 , indicating that submicron particles were the major light-scattering components in the air masses arriving at the Hok Tsui station. For most of the time in the study period, the simulated $\sigma_{\mathrm{sp}}$ was lower than the observed $\sigma_{\mathrm{sp}}$. This is probably because the particle size distribution data from the UFPM only used the scanned submicron particles with mobility diameter from 20 to $800 \mathrm{~nm}$ (see Fig. 6b and c) in the calculation, but the nephelometer, equipped with a TSP inlet, measured light-scattering coefficients from all particles with a wider-sized range. The relatively limited number of particle size bins in the UFPM probably also leads to uncertainties for the calculation of $\sigma_{\mathrm{sp}}$. Hence, this result can only provide a rough image of the relationships between particle light scattering and their size distribution at the Hok Tsui station. It can be observed that particles with $D_{\mathrm{p}}$ less than $200 \mathrm{~nm}$ contributed the largest fraction of the total number of submicron particles but very little to the total scattering, whereas the small amount of larger particles $\left(D_{\mathrm{p}}: 200-800 \mathrm{~nm}\right)$ contributed the most to the total light scattering.

The scatter plot (Fig. 6a) also shows that there were clusters of data where the modeled and measured $\sigma_{\mathrm{sp}}$ fit close to the $1: 1$ line and clusters where the measured $\sigma_{\mathrm{sp}}$ was clearly larger than those modeled on. After computing the averaged retroplume of these clusters, it was found that the former data cluster is mostly associated with polluted continental air and the latter with stronger winds and sea-salt particles (figures were not shown).

\subsection{Source identification}

Figure 7 shows the spatial distribution of $\mathrm{BC} / \mathrm{CO}$ emission ratios in East China and the nearby regions calculated using the MIX emission inventory. It can be seen that the $\mathrm{BC} / \mathrm{CO}$ emission ratio was higher in Shanxi Province (higher than $25 \mathrm{ng} \mathrm{m}^{-3} \mathrm{ppbv}^{-1}$ ), Taiwan (approximately $20 \mathrm{ng} \mathrm{m}^{-3} \mathrm{ppbv}^{-1}$ ), and the regions along the coastline of East China. As reported by previous studies, the $\mathrm{BC} / \mathrm{CO}$ emission ratio from industrial coal burning ranges 

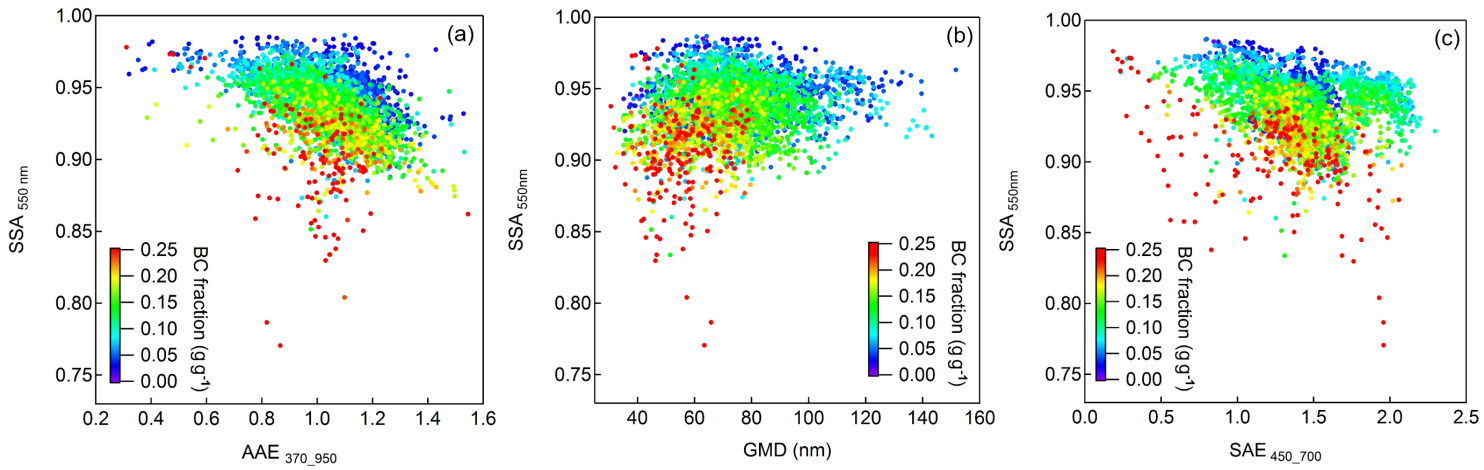

Figure 5. (a) Scatter plot of $\mathrm{SSA}_{550 \mathrm{~nm}}$ and AAE, (b) $\mathrm{SSA}_{550 \mathrm{~nm}}$ and GMD, and (c) $\mathrm{SSA}_{550 \mathrm{~nm}}$ and $\mathrm{SAE}_{450} 700 \mathrm{~nm}$, color-coded with BC mass fraction of $\mathrm{PM}_{1}$.
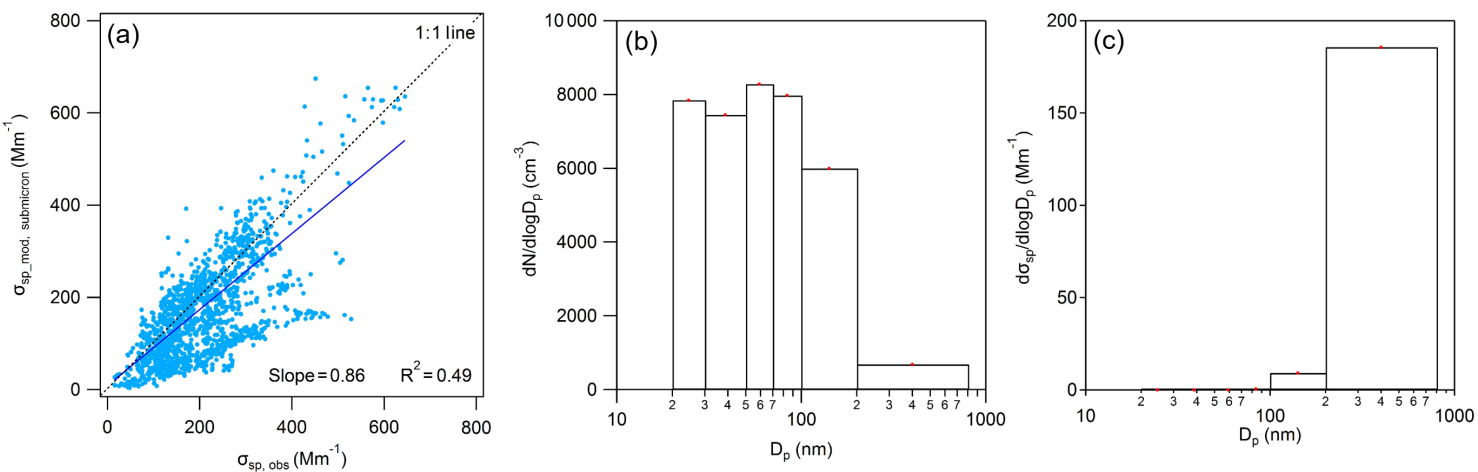

Figure 6. (a) Scatter plot of simulated $\sigma_{\mathrm{sp}}$ submicron particles and observed $\sigma_{\mathrm{sp}}$ at $\lambda=550 \mathrm{~nm}$. (b) Average number size distribution and (c) scattering size distribution during the whole period.

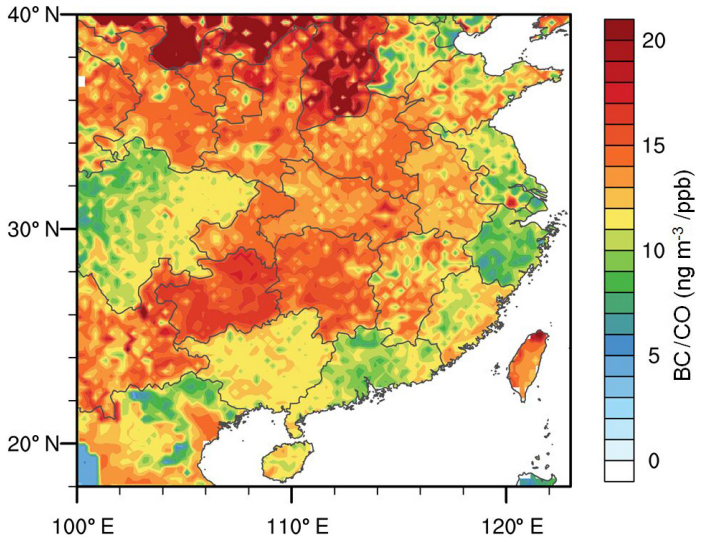

Figure 7. Map showing spatial distribution of $\mathrm{BC} / \mathrm{CO}$ emission ratio with grid resolution of $\left(0.25^{\circ} \times 0.25^{\circ}\right)$ from MIX Asian emission inventory (Li et al., 2017).

from 1.9 to 20 and it was $5.6-13.3 \mathrm{ng} \mathrm{m}^{-3} \mathrm{ppbv}^{-1}$ from open biomass burning (Wang et al., 2011; Zhang et al., 2009). For diesel vehicles, the $\mathrm{BC} / \mathrm{CO}$ emission ratio was $14-39$ and it was $15.6 \mathrm{ng} \mathrm{m}^{-3} \mathrm{ppbv}^{-1}$ for ship emission calculated from a previous study in southern Asia (Dickerson et al., 2002).

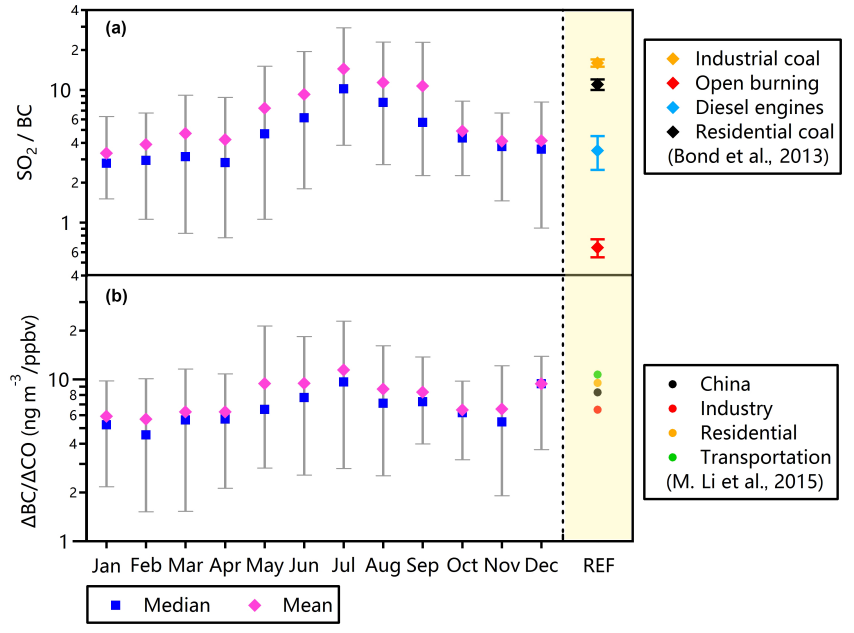

Figure 8. Seasonal cycles of $\triangle \mathrm{BC} / \triangle \mathrm{CO}$ and $\mathrm{SO}_{2} / \mathrm{BC}$ ratios from observations. Reference values of emission ratios from different source types are shown in the column with light-yellow background.

A strong correlation between $\mathrm{BC}$ and $\mathrm{CO}$ and a high slope of $27 \times 10^{-3} \mathrm{~g} \mathrm{BC} \mathrm{g} \mathrm{CO}^{-1}$ were found from a previous study using C-130 aircraft flew over the Arabian Sea and northern 


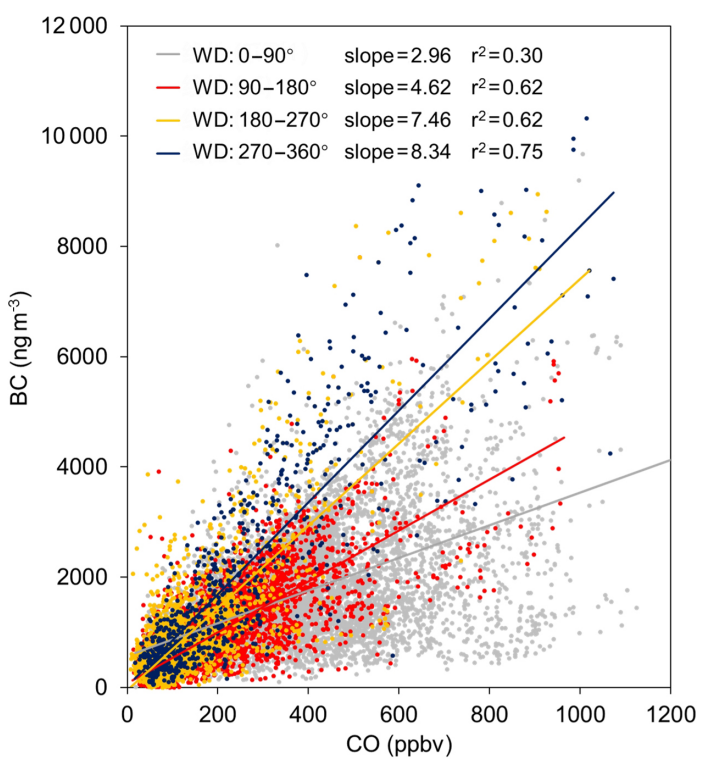

Figure 9. Scatter plot of hourly BC and CO in four wind sectors.

Indian Ocean (Dickerson et al., 2002; Mayol-Bracero et al., 2002).

In this study, $\triangle \mathrm{BC} / \triangle \mathrm{CO}$ and $\mathrm{SO}_{2} / \mathrm{BC}$ ratios were investigated to study the source characteristics and the freshness of the fuel combustion sources. $\triangle \mathrm{BC} / \triangle \mathrm{CO}$ (net growth of $\mathrm{BC}$ and $\mathrm{CO}$ : total concentration minus regional baseline. (Spackman et al., 2008) and $\mathrm{SO}_{2} / \mathrm{BC}$ were calculated with $1 \mathrm{~h}$ time resolution. The baseline of $\mathrm{BC}$ and $\mathrm{CO}$ was determined as 1.25th percentiles of data in each month (Pan et al., 2011). Monthly variation of $\triangle \mathrm{BC} / \triangle \mathrm{CO}$ is displayed in Fig. 8 together with $\mathrm{SO}_{2} / \mathrm{BC}$ to demonstrate the fuel burning emission profile since $\mathrm{SO}_{2}$ is a co-emitted species of fossil fuel combustion (Bond et al., 2013). Reference emission ratios of $\mathrm{BC} / \mathrm{CO}$ and $\mathrm{SO}_{2} / \mathrm{BC}$ from previous studies (Bond et al., 2013; Li et al., 2015) are also plotted in Fig. 8.

In Hong Kong, major $\mathrm{SO}_{2}$ emission was from navigation and public electricity generation, contributing 50 and $47 \%$ to total $\mathrm{SO}_{2}$ emission (Emission Inventory 2013, HKEPD, http://www.epd.gov.hk/epd/english/environmentinhk/air/ data/emission_inve.html). However, these two sources only took up 19 and $6 \%$ of $\mathrm{CO}$ emission and the largest contributor of $\mathrm{CO}$ reported in the emission inventory was road transport $(59 \%)$. As shown in Fig. 8, $\Delta \mathrm{BC} / \Delta \mathrm{CO}$ and $\mathrm{SO}_{2} / \mathrm{BC}$ ratios presented similar monthly variation patterns. The monthly mean $\triangle \mathrm{BC} / \triangle \mathrm{CO}$ ranged from 1.5 to $20 \mu \mathrm{g} \mathrm{m}^{-3} \mathrm{ppbv}^{-1}$ during the whole study period. The highest values occurred in summer months for both $\Delta \mathrm{BC} / \triangle \mathrm{CO}$ and $\mathrm{SO}_{2} / \mathrm{BC}$ and the ratios were relatively lower in winter. Since $\mathrm{SO}_{2}$ has a short lifetime, which can easily deposit and transform into secondary aerosols, the synchronous elevation of $\triangle \mathrm{BC} / \triangle \mathrm{CO}$ and $\mathrm{SO}_{2} / \mathrm{BC}$ in summer indicates that freshly emitted anthropogenic pollutants might be more easily influenced by the air masses in this coastal area. The decrease of $\triangle \mathrm{BC} / \Delta \mathrm{CO}$ and $\mathrm{SO}_{2} / \mathrm{BC}$ in winter provided the evidence that this area was under the influence of contaminated air masses from a longer distance. Figure 9 displays the scatter plot of BC vs. CO in four wind sectors, giving an image of the freshness of polluted air masses and the intensities of combustion emissions from different directions. For wind directions from 180 to $360^{\circ}$, the data points show a good positive correlation, suggesting that most of the $\mathrm{BC}$ and $\mathrm{CO}$ emission sources in these areas were closer to the measurement site. Data points in the $0-180^{\circ}$ wind direction sector were much more scattered with a lower slope of It should be 'delta BC / delta CO' of air pollutants coming from the northeast to the southeast. Through the transport of air plume, diffusion and deposition of air pollutants would decrease their concentrations that arrive to the receptor, and therefore lower the slope of $\triangle \mathrm{BC} / \triangle \mathrm{CO}$ and their correlation coefficients.

To investigate the transport pattern of air masses that arrived at the site during the study period, Fig. 10 shows averaged 7-day retroplume for four seasons. As presented in Ding et al. (2013), it shows a distinguished different transport pattern under the influence of Asian monsoons. During summer, the majority of air masses came from the south and nearby PRD cities. Due to the dominance of relatively clean marine air, emission from passing ships or local activities in adjacent regions could make visible effects on the temporal variations of air pollutants. The source distribution was more complicated during winter. Driven by the winter monsoon, cold and dry air masses that were transported along the coastline of East China and from central China took up a higher proportion in winter months (Ding et al., 2013). There were also air masses passing through Taiwan and the East China Sea during the cold season (Fig. 10a).

Since BC is the most significant light-absorbing constituent of aerosols, to evaluate the potential source contribution of light absorbing particles on regional optical properties, averaged PSC maps of BC for different transport times and seasons were calculated using the method described in Sect. 2.6 and illustrated in Fig. 11. However, here we only calculated the PSC from emission over land because the available emission inventory from the MIX database is mainly focused on land areas. As shown in Figs. 11a and 10b, $\mathrm{BC}$ concentrations were influenced by the transport from nearby cities within a short time, especially Shenzhen and urban Hong Kong. Long-range transport of BC from the South and East China also played an important contribution. It was also shown that $\mathrm{BC}$ coming from the continental area through longer distances took up a higher proportion of the pollutant level in winter (Fig. 11d) than that of the summer (Fig. 11c). During summer, local emission was the biggest BC contributor.

Figures 12a-11c illustrate the average levels of $\sigma_{\mathrm{ap}}, \sigma_{\mathrm{sp}}$ and $\mathrm{PM}_{1}$ and the corresponding frequency of occurrence for air masses passing through different regions calculated using Eq. (3). Together with the shipping routes density map 

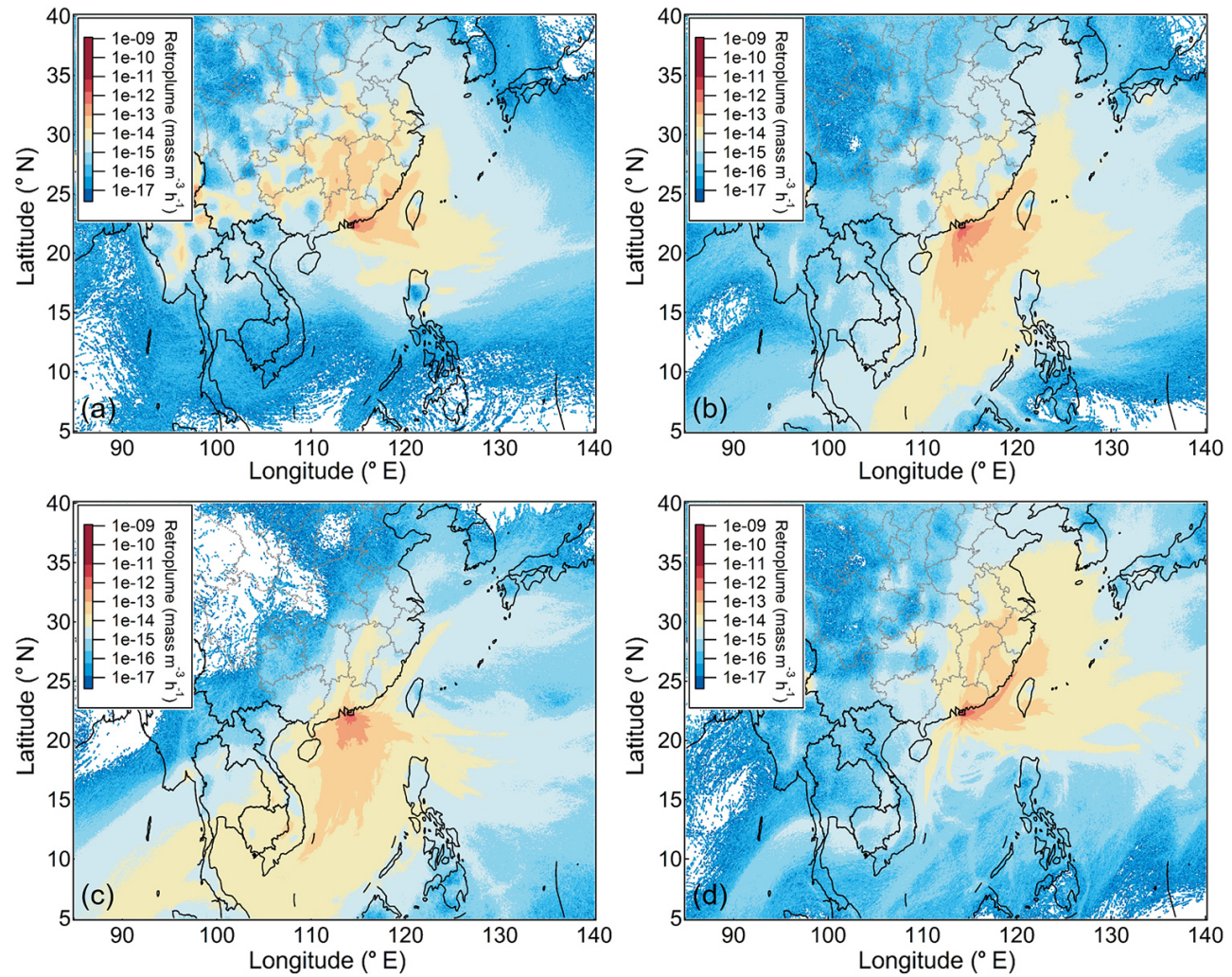

Figure 10. Map of averaged 7-day retroplume in (a) winter, (b) spring, (c) summer, and (d) autumn.

(Fig. 12d), it can be observed that the high levels of $\sigma_{\text {ap }}$ and $\sigma_{\mathrm{sp}}$ were closely associated with the congested shipping lanes in the maritime space nearby Hong Kong. The high $\sigma_{\text {ap }}$ and $\sigma_{\mathrm{sp}}$ were especially visible in the northeast due to the prevailing northeasterly wind from autumn to spring, transporting ship exhausts mainly through the Taiwan Strait. The beltlike zone with higher $\sigma_{\mathrm{ap}}$ and $\sigma_{\mathrm{sp}}$ was likely to reveal ship emission. As shown in Fig. 12d, there were dense shipping routes between Hong Kong and Singapore traveling through the Xisha Islands in the South China Sea where the routes were similar to the high $\sigma_{\text {ap }}$ area in the south. During summer, Hong Kong was influenced by the southerly and southwesterly wind, bringing clean marine air to this region for most of time and leading to lower pollutant levels (Wang et al., 2009; Ding et al., 2013). Figure 12 indicates that Hong Kong could be affected by the passing vessels in the South China Sea due to controlling wind direction, driven by the summer monsoon.

\subsection{Analyses of selected episodes}

Figure 13 demonstrates the aerosol optical properties and BC-CO correlations associated with air masses from different source regions during selected episodes. The major source regions were Guangdong and Hong Kong (GH), ship emission (SP), North China (NC), and the aged continen- tal area (AGC). The selection of the episodes was done by combining the footprints using LPDM and the variation trend of aerosol optical properties and $\mathrm{PM}_{2.5}$. The air pollution plumes coming from Guangdong and urban Hong Kong had the highest $\mathrm{BC}$ and $\mathrm{CO}$ concentrations (Fig. 13a), indicating a higher level of emission intensity and stronger light-extinction ability of aerosols from these regions. The slope of $\mathrm{BC}$ vs. $\mathrm{CO}$ was highest from ship emission $\left(0.012 \mu \mathrm{g} \mathrm{m}^{-3} \mathrm{ppbv}^{-1}\right)$, with high correlation $\left(r^{2}=0.84\right)$, showing that the ship emission source was close to the measurement station and its exhausts could largely affect the pollution level.

Figure 13b displays that Ångström exponents of scattering, from Guangdong and Hong Kong, were relatively high, compared to that from the aged continental area and North China, proving the dominance of smaller particles of emissions from PRD cities and passing ships. BC-containing particles transported from North and East China went through longer coating and deposition processes, which enlarged their size but decreased their concentrations when arriving to the measurement site. This can further explain the lower SSA in summer months.

Overall, the analyses suggest that aerosols from different source regions could cause great variances on regional aerosol optical properties. Thus, more ground observations of aerosol optical properties are needed to fully understand 

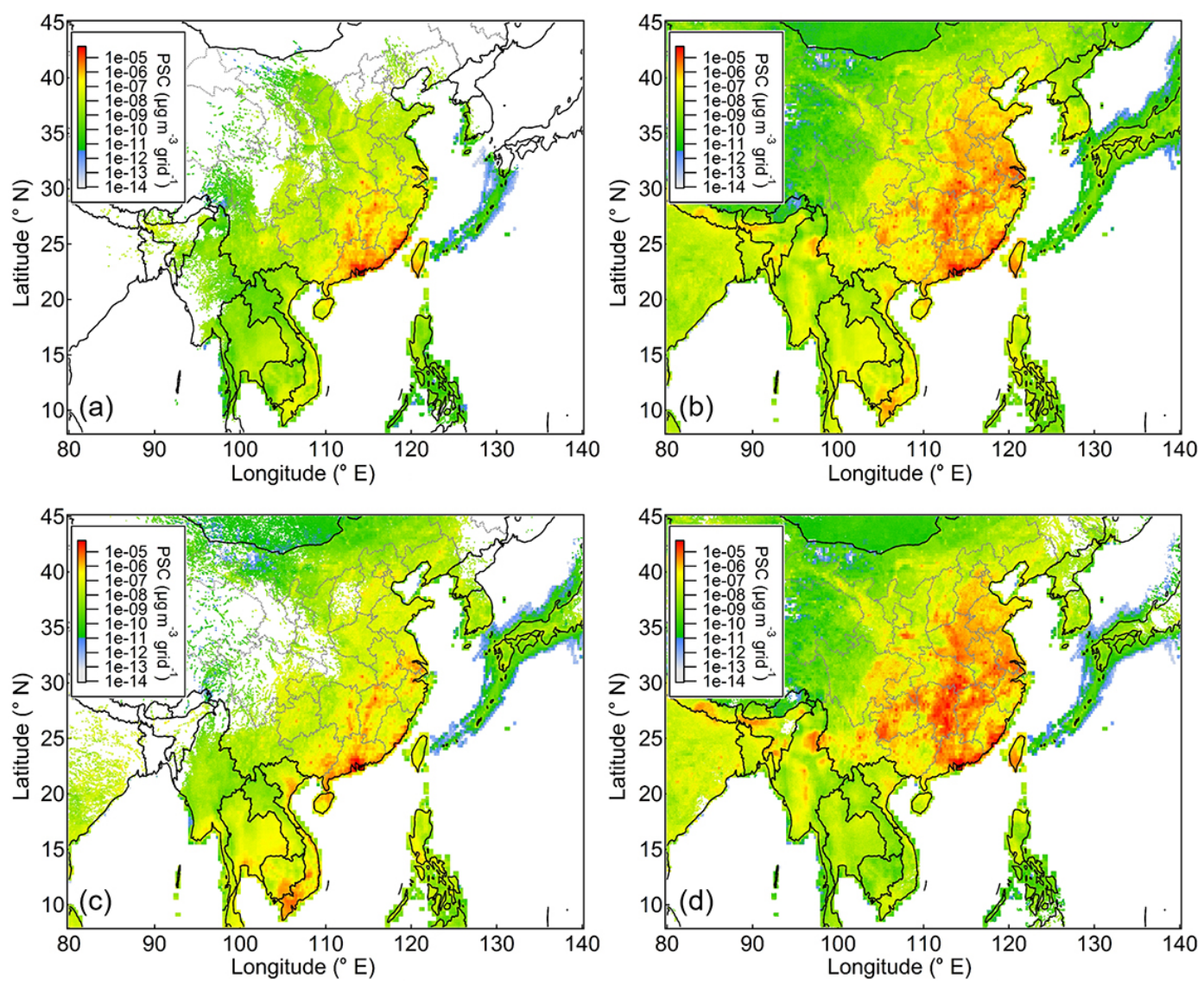

Figure 11. (a, b) :Map of averaged potential source contribution of BC with a backward-transport age of (a) 2 days, (b) 7 days for the whole measurement period. (c, d) :averaged 7-day PSC in (c) summer, (d) winter.

the characteristics of different types of atmospheric aerosols and provide reference datasets for further investigation of aerosol radiative forcing and climatic effects.

\section{Conclusions}

Based on aerosol optical properties, relevant species and aerosol size measured at Hok Tsui station in Hong Kong, we studied the temporal variations and investigated the potential sources by using correlation analysis and Lagrangian dispersion modeling. Overall, the absorption coefficients at the site in the South China coastal region were lower than most of other rural sites in eastern China. Scattering coefficients observed in this study were almost twice the values monitored at the same station in 1998, yet BC concentrations decreased over 50\% compared with the measurements in 2004. The darkest aerosols were smaller in particle size but showed strong scattering wavelength dependencies, indicating possible sources from fresh emissions close to the measurement site. Particles with $D_{\mathrm{p}}$ of $200-800 \mathrm{~nm}$ were less in number, yet contributed the most to the light-scattering coefficients among submicron particles.
A remarkable correlation was found for $\mathrm{BC}$ and $\mathrm{CO}$ concentrations during episodes. $\triangle \mathrm{BC} / \triangle \mathrm{CO}$ range from 1.5 to $20 \mu \mathrm{g} \mathrm{m}^{-3} \mathrm{ppb}^{-1}$ during whole period. Both $\Delta \mathrm{BC} / \Delta \mathrm{CO}$ and $\mathrm{SO}_{2} / \mathrm{BC}$ peaked in summer months and were relatively low in spring and autumn. In summer, the site was affected by nearby combustion sources, while in spring and autumn the observed air masses were more under the influence of well-mixed air masses from long-range transport. Multi-year backward LPDM and PSC analysis together with case studies provided detailed information of the transport of air masses and their impacts on aerosol optical properties. For summer months, air masses moved southward over Shenzhen, and urban Hong Kong brought air pollutants mainly from residential and transportation to the measurement site, showing strong light absorbing ability; ship exhausts were introduced into the southerly marine air with higher speed, showing a strong positive correlation between BC and CO. These fresh emission sources led to low SSA during the summer. For winter and autumn months, the air plume arriving at Hok Tsui station was a mixture of multi-source aerosol including air masses from South China, East China coastal regions, and aged aerosol transported over the Pacific Ocean and Taiwan, causing stronger abilities of light extinction and larger 

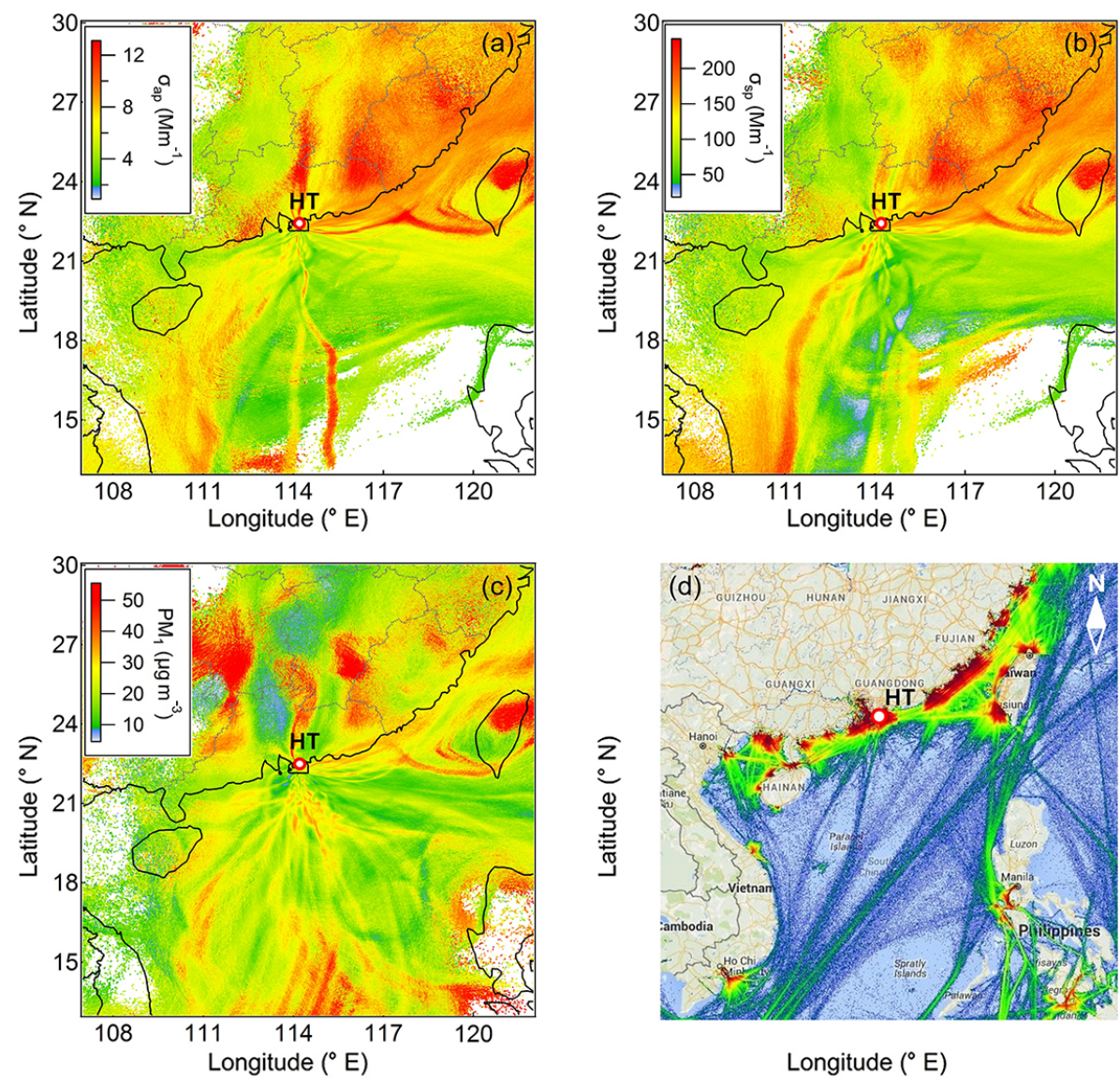

Figure 12. Map of average property retroplume $_{\text {for }}$ (a) $\sigma_{\mathrm{ap}}$, (b) $\sigma_{\mathrm{sp}}$, and (c) $\mathrm{PM}_{1}$ (the non-colored areas were where the total retroplume was smaller than $10^{-12}$ mass $\mathrm{m}^{-3} \mathrm{~h}^{-1}$ (i.e., air plumes barely passed through these regions). Due to the different time period of valid data from UFP, the non-colored areas were slightly different in (c). (d) Density map showing the ship routes near Hong Kong during 2013 and 2014.
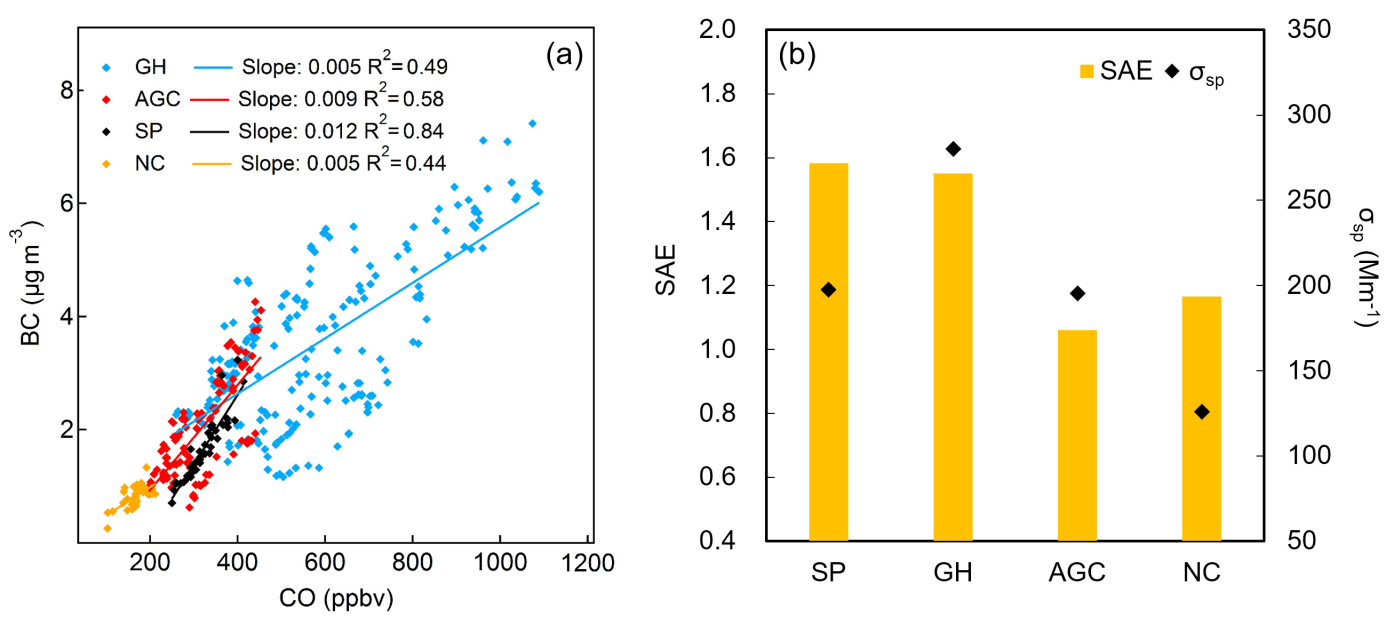

Figure 13. (a) Scatter plots of BC and CO. (b) $\sigma_{\mathrm{sp}}$ and SAE from different source regions during episodes GH: Guangdong and Hong Kong; SP: Ship; NC: North China; and the AGC: aged continental area. 
variability of aerosol optical properties as well as pollutant concentrations.

\section{Data availability}

The data can be accessed upon contact with the corresponding authors.

Competing interests. The authors declare that they have no conflict of interest.

Acknowledgements. The data measurement of this study was supported by the HK project (H-ZDA8), the Research Grants Council of the Hong Kong Government (PolyU 152083/14E, PolyU 152090/15E) and the Hong Kong RGC Collaborative Research Fund (C5022-14G). The data analysis was supported by NSFC (D0512/91544231), the National Special Research Fund for Non-Profit Sector (Environmental Protection; no. 201509004). The authors would like to thank Steven Poon for the support of trace gases measurement at the Hok Tsui Site, and would like to thank Ding Ke for useful discussions.

Edited by: I. Salma

Reviewed by: two anonymous referees

\section{References}

Anderson, T. L. and Ogren, J. A.: Determining Aerosol Radiative Properties Using the TSI 3563 Integrating Nephelometer, Aerosol Sci. Technol., 29, 57-69, 1998.

Andriejauskienė, J.: Black carbon aerosol at the background site in the coastal zone of the Baltic Sea, Lith. J. Phys., 48, 183-194, 2008.

Babu, S. and Moorthy, K.: Anthropogenic impact on aerosol black carbon mass concentration at a tropical coastal station: A case study, Curr. Sci. India, 81, 1208-1214, 2001.

Bohren, C. F. and Huffman, D. R.: Absorption and scattering of light by small particles, Wiley New York, 1983.

Bond, T. C. and Bergstrom, R. W.: Light Absorption by Carbonaceous Particles: An Investigative Review, Aerosol Sci. Technol., 40, 27-67, 2006.

Bond, T. C., Doherty, S. J., Fahey, D. W., Forster, P. M., Berntsen, T., DeAngelo, B. J., Flanner, M. G., Ghan, S., Kärcher, B., Koch, D., Kinne, S., Kondo, Y., Quinn, P. K., Sarofim, M. C., Schultz, M. G., Schulz, M., Venkataraman, C., Zhang, H., Zhang, S., Bellouin, N., Guttikunda, S. K., Hopke, P. K., Jacobson, M. Z., Kaiser, J. W., Klimont, Z., Lohmann, U., Schwarz, J. P., Shindell, D., Storelvmo, T., Warren, S. G., and Zender, C. S.: Bounding the role of black carbon in the climate system: A scientific assessment, J. Geophys. Res.-Atmos., 118, 5380-5552, doi:10.1002/jgrd.50171, 2013.

Cazorla, A., Bahadur, R., Suski, K. J., Cahill, J. F., Chand, D., Schmid, B., Ramanathan, V., and Prather, K. A.: Relating aerosol absorption due to soot, organic carbon, and dust to emission sources determined from in-situ chemical measurements, Atmos. Chem. Phys., 13, 9337-9350, doi:10.5194/acp-13-9337-2013, 2013.

Chamaillard, K., Kleefeld, C., Jennings, S., Ceburnis, D., and Dowd, C.: Light scattering properties of sea-salt aerosol particles inferred from modeling studies and ground-based measurements, J. Quant. Spectrosc. Ra., 101, 498-511, 2006.

Cheng, I., Xu, X., and Zhang, L.: Overview of receptor-based source apportionment studies for speciated atmospheric mercury, Atmos. Chem. Phys., 15, 7877-7895, doi:10.5194/acp-15-78772015, 2015.

Cheng, Y. F., Lee, S., Ho, K., Wang, Y., Cao, J., Chow, J., and Watson, J.: Black carbon measurement in a coastal area of south China, J. Geophys. Res.-Atmos., 111, D12310, doi:10.1029/2005JD006663, 2006a.

Cheng, Y. F., Eichler, H., Wiedensohler, A., Heintzenberg, J., Zhang, Y. H., Hu, M., Herrmann, H., Zeng, L. M., Liu, S., Gnauk, T., Brüggemann, E., and He, L. Y.: Mixing state of elemental carbon and non-light-absorbing aerosol components derived from in situ particle optical properties at Xinken in Pearl River Delta of China, J. Geophys. Res., 111, D20204, doi:10.1029/2005JD006929, 2006b.

Cheng, Y. F., Wiedensohler, A., Eichler, H., Su, H., Gnauk, T., Bruggemann, E., Herrmann, H., Heintzenberg, J., Slanina, J., Tuch, T., Hu, M., and Zhang, Y.: Aerosol optical properties and related chemical apportionment at Xinken in Pearl River Delta of China, Atmos. Environ., 42, 6351-6372, 2008.

Collaud Coen, M., Weingartner, E., Apituley, A., Ceburnis, D., Fierz-Schmidhauser, R., Flentje, H., Henzing, J. S., Jennings, S. G., Moerman, M., Petzold, A., Schmid, O., and Baltensperger, U.: Minimizing light absorption measurement artifacts of the Aethalometer: evaluation of five correction algorithms, Atmos. Meas. Tech., 3, 457-474, doi:10.5194/amt-3-457-2010, 2010.

Delene, D. J. and Ogren, J. A.: Variability of aerosol optical properties at four North American surface monitoring sites, J. Atmos. Sci., 59, 1135-1150, 2002.

Devi, J. J., Bergin, M., McKenzie, M., Schauer, J. J., and Weber, R.: Contribution of particulate brown carbon to light absorption in the rural and urban Southeast US, Atmos. Environ., 136, 95104, 2016.

Dickerson, R., Andreae, M., Campos, T., Mayolbracero, O., Neusuess, C., and Streets, D.: Analysis of black carbon and carbon monoxide observed over the Indian Ocean: Implications for emissions and photochemistry, J. Geophys. Res., 107, 8017, doi:10.1029/2001JD000501, 2002.

Ding, A., Wang, T., Zhao, M., Wang, T., and Li, Z.: Simulation of sea-land breezes and a discussion of their implications on the transport of air pollution during a multi-day ozone episode in the Pearl River Delta of China, Atmos. Environ., 38, 6737-6750, 2004.

Ding, A., Wang, T., and Fu, C.: Transport characteristics and origins of carbon monoxide and ozone in Hong Kong, South China, J. Geophys. Res.-Atmos., 118, 9475-9488, 2013.

Ding, A. J., Huang, X., Nie, W., Sun, J. N., Kerminen, V.-M., Petäjä, T., Hang, S., Cheng, Y. F., Yang, X.-Q., Wang, M. H., Chi, X. G., Wang, J. P., Virkkula, A., Guo, W.D., Yuan, J., Wang, S. Y., Zhang, R. J., Wu, Y. F., Song, Y., Zhu, T., Zilitinkevich, S., Kulmala, M., and Fu, C. B.: Enhanced haze pollution by black car- 
bon in megacties in China, Geophys. Res. Lett., 43, 2873-2879, doi:10.1002/2016GL067745, 2016.

Dubovik, O., Holben, B., Eck, T. F., Smirnov, A., Kaufman, Y. J., King, M. D., Tanré, D., and Slutsker, I.: Variability of absorption and optical properties of key aerosol types observed in worldwide locations, J. Atmos. Sci., 59, 590-608, 2002.

Draxler, R. R. and Hess, G.: An overview of the HYSPLIT_ 4 modelling system for trajectories, Aust. Meteorol. Mag., 47, 295308, 1998.

Girach, I., Nair, V., Babu, S., and Nair, P.: Black carbon and carbon monoxide over Bay of Bengal during W_ICARB: Source characteristics, Atmos. Environ., 94, 508-517, 2014.

Gómez-Moreno, F. J., Alonso, E., Artíñano, B., Juncal-Bello, V., Iglesias-Samitier, S., Piñeiro Iglesias, M., Lopez Mahía, P., Perez, N., Pey, J., Ripoll, A., Alastuey, A., De la Morena, B. A., García, M. I., Rodríguez, S., Sorribas, M., Titos, G., Lyamani, H., Alados-Arboledas, L., Latorre, E., Tritscher, T., and Bischof, O.: Intercomparisons of mobility size spectrometers and condensation particle counters in the frame of the Spanish atmospheric observational aerosol network, Aerosol Sci. Technol. 49, 777785, doi:10.1080/02786826.2015.1074656, 2015.

Gyawali, M., Arnott, W. P., Lewis, K., and Moosmüller, H.: In situ aerosol optics in Reno, NV, USA during and after the summer 2008 California wildfires and the influence of absorbing and non-absorbing organic coatings on spectral light absorption, Atmos. Chem. Phys., 9, 8007-8015, doi:10.5194/acp-9-8007-2009, 2009.

Hegg, D., Covert, D., Crahan, K., and Jonssen, H.: The dependence of aerosol light-scattering on RH over the Pacific Ocean, Geophys. Res. Lett., 29, doi:10.1029/2001GL014495, 2002.

Hillemann, L., Zschoppe, A., Caldow, R., Sem, G. J., and Wiedensohler, A.: An Ultrafine Particle Monitor for Size-resolved Number Concentration Measurements in Atmospheric Aerosols, J. Aerosol Sci., 68, 14-24, 2014.

Hyvarinen, A., Kolmonen, P., Kerminen, V., Virkkula, A., Leskinen, A., Komppula, M., Hatakka, J., Burkhart, J., Stohl, A., Aalto, P., Kulmala, M., Lehtinen, K., Viisanen, Y., and Lihavainen, H.: Aerosol black carbon at five background measurement sites over Finland, a gateway to the Arctic, Atmos. Environ., 45, 40424050, 2011.

Jacobson, M. Z.: Strong radiative heating due to the mixing state of black carbon in atmospheric aerosols, Nature, 409, 695-697, 2001

Jennings, S., Spain, T., Doddridge, B., Maring, H., Kelly, B., and Hansen, A.: Concurrent measurements of black carbon aerosol and carbon monoxide at Mace Head, J. Geophys. Res., 101, 19447-19454, 1996.

Kirchstetter, T., Novakov, T., and Hobbs, P.: Evidence that the spectral dependence of light absorption by aerosols is affected by organic carbon, J. Geophys. Res., 109, 2004.

Kuhlbusch, T., John, A., and Fissan, H.: Diurnal variations of aerosol characteristics at a rural measuring site close to the RuhrArea, Germany, Atmos. Environ., 35, S13-S21, 2001.

Lack, D. A. and Cappa, C. D.: Impact of brown and clear carbon on light absorption enhancement, single scatter albedo and absorption wavelength dependence of black carbon, Atmos. Chem. Phys., 10, 4207-4220, doi:10.5194/acp-10-4207-2010, 2010.

Lam, K., Wang, T., Chan, L., Wang, T., and Harris, J.: Flow patterns influencing the seasonal behavior of surface ozone and carbon monoxide at a coastal site near Hong Kong, Atmos. Environ., 35, 3121-3135, 2001.

Li, M., Zhang, Q., Kurokawa, J.-I., Woo, J.-H., He, K., Lu, Z., Ohara, T., Song, Y., Streets, D. G., Carmichael, G. R., Cheng, Y., Hong, C., Huo, H., Jiang, X., Kang, S., Liu, F., Su, H., and Zheng, B.: MIX: a mosaic Asian anthropogenic emission inventory under the international collaboration framework of the MICS-Asia and HTAP, Atmos. Chem. Phys., 17, 935-963, doi:10.5194/acp17-935-2017, 2017

Liu, H. and Chan, J. C.: An investigation of air-pollutant patterns under sea-land breezes during a severe air-pollution episode in Hong Kong, Atmos. Environ., 36, 591-601, 2002.

Lyamani, H., Olmo, F. J., and Alados-Arboledas, L.: Physical and optical properties of aerosols over an urban location in Spain: seasonal and diurnal variability, Atmos. Chem. Phys., 10, 239254, doi:10.5194/acp-10-239-2010, 2010.

Man, C. and Shih, M.: Light scattering and absorption properties of aerosol particles in Hong Kong, J. Aerosol Sci., 32, 795-804, 2001.

Mayol-Bracero, O., Gabriel, R., Andreae, M., Kirchstetter, T., Novakov, T., Ogren, J., Sheridan, P., and Streets, D.: Carbonaceous aerosols over the Indian Ocean during the Indian Ocean Experiment (INDOEX): Chemical characterization, optical properties, and probable sources, J. Geophys. Res., 107, 8030, doi:10.1029/2000JD000039, 2002.

Mikhailov, E., Vlasenko, S., Podgorny, I., Ramanathan, V., and Corrigan, C.: Optical properties of soot-water drop agglomerates: An experimental study, J. Geophys. Res., 111, 1-16, 2006.

Mogo, S., Cachorro, V. E., Lopez, J. F., Montilla, E., Torres, B., Rodríguez, E., Bennouna, Y., and de Frutos, A. M.: In situ measurements of aerosol optical properties and number size distributions in a coastal region of Norway during the summer of 2008, Atmos. Chem. Phys., 12, 5841-5857, doi:10.5194/acp-12-58412012, 2012.

Moosmüller, H. and Chakrabarty, R. K.: Technical Note: Simple analytical relationships between Ångström coefficients of aerosol extinction, scattering, absorption, and single scattering albedo, Atmos. Chem. Phys., 11, 10677-10680, doi:10.5194/acp-1110677-2011, 2011.

Moosmüller, H., Chakrabarty, R. K., Ehlers, K. M., and Arnott, W. P.: Absorption Ångström coefficient, brown carbon, and aerosols: basic concepts, bulk matter, and spherical particles, Atmos. Chem. Phys., 11, 1217-1225, doi:10.5194/acp-11-12172011, 2011.

Pan, X. L., Kanaya, Y., Wang, Z. F., Liu, Y., Pochanart, P., Akimoto, H., Sun, Y. L., Dong, H. B., Li, J., Irie, H., and Takigawa, M.: Correlation of black carbon aerosol and carbon monoxide in the high-altitude environment of Mt. Huang in Eastern China, Atmos. Chem. Phys., 11, 9735-9747, doi:10.5194/acp-11-97352011, 2011.

Pitz, M., Cyrys, J., Karg, E., Wiedensohler, A., Wichmann, H. E., and Heinrich, J.: Variability of apparent particle density of an urban aerosol, Environ. Sci. Technol., 37, 4336-4342, 2003.

Quinn, P., Coffman, D., Bates, T., Miller, T., Johnson, J., Voss, K., Welton, E., and Neusüss, C.: Dominant aerosol chemical components and their contribution to extinction during the Aerosols99 cruise across the Atlantic, J. Geophys. Res.-Atmos., 106, 20783 20809, 2001. 
Russell, P. B., Bergstrom, R. W., Shinozuka, Y., Clarke, A. D., DeCarlo, P. F., Jimenez, J. L., Livingston, J. M., Redemann, J., Dubovik, O., and Strawa, A.: Absorption Angstrom Exponent in AERONET and related data as an indicator of aerosol composition, Atmos. Chem. Phys., 10, 1155-1169, doi:10.5194/acp-101155-2010, 2010.

Saarikoski, S., Mäkelä, T., Hillamo, R., Aalto, P., Kerminen, V.-M., and Kulmala, M.: Physico-chemical characterization and mass closure of size-segregated atmospheric aerosols in Hyytiälä, Finland, Boreal Environ. Res., 10, 385-400, 2005.

Saha, A. and Despiau, S.: Seasonal and diurnal variations of black carbon aerosols over a Mediterranean coastal zone, Atmos. Res., 92, 27-41, 2009.

Schnaiter, M., Horvath, H., Mohler, O., Naumann, K. H., Saathoff, H., and Schock, O. W.: UV-VIS-NIR spectral optical properties of soot and soot-containing aerosols, J. Aerosol Sci., 34, 14211444, 2003.

Schnaiter, M., Linke, M., Möhler, O., Naumann, K.-H., Saathoff, H., Wagner, R., Schurath, U., and Wehner, B.: Absorption Amplification of Black Carbon Internally Mixed with Secondary Organic Aerosol, J. Geophys. Res., 110, D19204, doi:10.1029/2005JD006046, 2005.

Schuster, G. L., Dubovik, O., and Holben, B. N.: Angstrom Exponent and Bimodal Aerosol Size Distributions, J. Geophys. Res., 111, D07207, doi:10.1029/2005JD006328, 2006.

Spackman, J., Schwarz, J., Gao, R., Watts, L., Thomson, D., Fahey, D., Holloway, J., De Gouw, J., Trainer, M., and Ryerson, T.: Empirical correlations between black carbon aerosol and carbon monoxide in the lower and middle troposphere, Geophys. Res. Lett., 35, L19816, doi:10.1029/2008GL035237, 2008.

Stein, A. F., Draler, R. R., Rolph, G. D., Stunder, B. J. B., Cohen, M. D., and Ngan, F.: NOAA's HYSPLIT Atmospheric Transport and Dispersion Modeling System, B. Am. Meteorol. Soc., 96, 2059-2077, doi:10.1175/BAMS-D-14-00110.1, 2015.

Stocker, T., Qin, D., Plattner, G., Tignor, M., Allen, S., Boschung, J., Nauels, A., Xia, Y., Bex, B., and Midgley, B.: IPCC, 2013: climate change 2013: the physical science basis. Contribution of working group I to the fifth assessment report of the intergovernmental panel on climate change, Cambridge University Press, 2013.

Stohl, A.: Trajectory statistics-a new method to establish source receptor relationships of air pollutants and its application to the transport of particulate sulfate in Europe, Atmos. Environ., 30, 579-587, 1996.

Tan, H., Liu, L., Fan, S., Li, F., Yin, Y., Cai, M., and Chan, P. W.: Aerosol optical properties and mixing state of black carbon in the Pearl River Delta, China, Atmos. Environ., 131, 196-208, 2016.

Tang, I.: Chemical and size effects of hygroscopic aerosols on light scattering aerosols, J. Geophys. Res., 101, 19245-19250, 1996.

Valenzuela, A., Olmo, F. J., Lyamani, H., Antón, M., Titos, G., Cazorla, A., and Alados-Arboledas, L.: Aerosol scattering and absorption Angström exponents as indicators of dust and dust-free days over Granada (Spain), Atmos Res., 154, 1-13, 2015.

Verma, R. L., Sahu, L. K., Kondo, Y., Takegawa, N., Han, S., Jung, J. S., Kim, Y. J., Fan, S., Sugimoto, N., Shammaa, M. H., Zhang, Y. H., and Zhao, Y.: Temporal variations of black carbon in Guangzhou, China, in summer 2006, Atmos. Chem. Phys., 10, 6471-6485, doi:10.5194/acp-10-6471-2010, 2010.
Virkkula, A., Mäkelä, T., Hillamo, R., Yli-Tuomi, T., Hirsikko, A., Hämeri, K., and Koponen, I. K.: A simple procedure for correcting loading effects of aethalometer data, J. Air Waste Manage. Assoc., 57, 1214-1222, 2007.

Virkkula, A., Backman, J., Aalto, P. P., Hulkkonen, M., Riuttanen, L., Nieminen, T., dal Maso, M., Sogacheva, L., de Leeuw, G., and Kulmala, M.: Seasonal cycle, size dependencies, and source analyses of aerosol optical properties at the SMEAR II measurement station in Hyytiälä, Finland, Atmos. Chem. Phys., 11, 4445-4468, doi:10.5194/acp-11-4445-2011, 2011.

Wang, T., Ding, A., Blake, D., Zahorowski, W., Poon, C., and Li, Y.: Chemical characterization of the boundary layer outflow of air pollution to Hong Kong during February-April 2001, J. Geophys. Res.-Atmos., 108, 8787, doi:10.1029/2002JD003272, 2003.

Wang, T., Wei, X. L., Ding, A. J., Poon, C. N., Lam, K. S., Li, Y. S., Chan, L. Y., and Anson, M.: Increasing surface ozone concentrations in the background atmosphere of Southern China, 1994 2007, Atmos. Chem. Phys., 9, 6217-6227, doi:10.5194/acp-96217-2009, 2009.

Wang, Y., Wang, X., Kondo, Y., Kajino, M., Munger, J., and Hao, J.: Black carbon and its correlation with trace gases at a rural site in Beijing: Top constraints from ambient measurements on bottom up emissions, J. Geophys. Res., 116, D24304, doi:10.1029/2011JD016575, 2011.

Wu, D., Mao, J., Deng, X., Tie, X., Zhang, Y., Zeng, L., Li, F., Tan, H., Bi, X., Huang, X., Chen, J., and Deng, T.: Black carbon aerosols and their radiative properties in the Pearl River Delta region, Sci. China Ser. D, 52, 1152-1163, doi:10.1007/s11430009-0115-y, 2009.

Xu, J., Bergin, M., Yu, X., Liu, G., Zhao, J., Carrico, C., and Baumann, K.: Measurement of aerosol chemical, physical and radiative properties in the Yangtze delta region of China, Atmos. Environ., 36, 161-173, 2002.

Yan, P., Tang, J., Huang, J., Mao, J. T., Zhou, X. J., Liu, Q., Wang, Z. F., and Zhou, H. G.: The measurement of aerosol optical properties at a rural site in Northern China, Atmos. Chem. Phys., 8, 2229-2242, doi:10.5194/acp-8-2229-2008, 2008.

Yau, P., Lee, S., Corbett, J., Wang, C., Cheng, Y., and Ho, K.: Estimation of exhaust emission from ocean-going vessels in Hong Kong, Sci. Total Environ., 431, 299-306, 2012.

Wu, D., Wu, C., Liao, B., Chen, H., Wu, M., Li, F., Tan, H., Deng, T., Li, H., Jiang, D., and Yu, J. Z.: Black carbon over the South China Sea and in various continental locations in South China, Atmos. Chem. Phys., 13, 12257-12270, doi:10.5194/acp13-12257-2013, 2013.

Zhang, Q., Streets, D. G., Carmichael, G. R., He, K. B., Huo, H., Kannari, A., Klimont, Z., Park, I. S., Reddy, S., Fu, J. S., Chen, D., Duan, L., Lei, Y., Wang, L. T., and Yao, Z. L.: Asian emissions in 2006 for the NASA INTEX-B mission, Atmos. Chem. Phys., 9, 5131-5153, doi:10.5194/acp-9-5131-2009, 2009.

Zhang, R., Khalizov, A. F., Pagels, J., Zhang, D., Xue, H., and McMurry, P. H.: Variability in morphology, hygroscopicity, and optical properties of soot aerosols during atmospheric processing, P. Natl. Acad. Sci. USA, 105, 10291-10296, 2008. 
Zhang, Y., Mao, H., Ding, A., Zhou, D., and Fu, C.: Impact of synoptic weather patterns on spatio-temporal variation in surface $\mathrm{O}_{3}$ levels in Hong Kong during 1999-2011, Atmos. Environ., 73, 41-50, 2013.
Zhou, D., Ding, A., Mao, H., Fu, C., Wang, T., Chan, L. Y., Ding, K., Zhang, Y., Liu, J., and Lu, A.: Impacts of the East Asian monsoon on lower tropospheric ozone over coastal South China, Environ. Res. Lett., 8, 044011, doi:10.1088/1748-9326/8/4/044011, 2013. 